\title{
ŚWIĘTOŚĆ MAŁŻEŃSTWA I RODZINY WEDŁUG KLEMENSA ALEKSANDRYJSKIEGO
}

Laterlaz źódłowy zawarty pismach Klemensa Aleksandryjskiego na temat małzeństwa i rodziny jest tak ogromny 1 bogaty swej rbznorodnośc1, ze trudno dziwić się, iz stał sie podstawa licznyoh opracowan ${ }^{1}$, których nie podobna nie zwrócić uwagi na dwie nowsze pozycje ksiązkowe: Folgiani, Storia del cristianesimo, Torino 196465 /Parte I: Problemi o controversie intorno al matrimonio all'1niz10 del III secolo cristiang/: J.P.Broudéhoux, Marlage et famille chez Clément d'Alexandrie, Paris 1970. F.Bolgiani, wyzej wymienionej pracy, zają sie głównie zebraniem tekstów zródłowych pochodzacych z począków III $w$. tym równiez wypowiedzi Klemensa Aleksandryjsklego, dotyczacych mazzenstwa, z podaniem komentarza wiazącego, jednak bez systematycznego wykładu tej problematyki. J.P.Broudéhoux, - mlare wyczerpujaco, uwzględniz owej monograf11 szeroki wachlarz problembr związanych pośrednio 1 bezpośrednio z małzeństwem 1 rodziną, zajmując sie zarówno sprawami pochodzenia mazzeństwa/s.74/, jego celu $/ 8.77 /$, dóbr zwiazanych z małzeństwem waspekcio religijnym /8.79/, spozecznym /s.80/, osob1stym /s.81/, materialnym /s.81/. moralnym $/ 8.82 /$. Jak 1 równiez problemaml celibatu /s.99/, dz1ew1ctwa /8.104/, dziowictwa 1 mazzeństwa/s.107/. Ten zbyt szeroki zakres omawianej problematyk1 nie pozwol11 autorowi na dokładne omowienle poszczególnych kwest11. z tej racji tez problem śrietości mazzoristwa i rodziny zostaz potraktowany zbyt ogólnie.

1 Z wazniejszych mozna wymlente: F.X.Funk, Clemens Alexandrinus tber Familie und Eigentum, TQ 53/1871/427-429; A. Orbe, El pecado original y el matrimonio en la teologia del secolo. II, "Gregor1anum" 43/1964/449-500; H.Prolsker, Christentum und Eho in den orsten drei Jahrhunderten, Berlin 1927; P.Stockmeier, Scheldung und Viederverheiratung in der alten K1rche, TQ 151/1971/ 39-51; F. Quatember, D1e christliche Lebenshaltung des Klemens von Aloxandrien nach seinem Padagogus, Wien 1946; C.Tiblletti, Verginitá $\theta$ matrimonio in antichi scrittor cristiani, Macerata $1983^{2}$. 
W zwazku z powyzszym postanowiono $\$$ ninlejszym artykule skupić się wyłącznie na zagadniontu świętośc1 małzeństra 1 rodziny, uwzględniając zarówno polemikę Klemensa z sektami atakująoymi instytucje mazzeństwa 1 rodziny, jak 1 pozytywny jego wykzad na tomat źódel świętości oraz programu uślįcania małzeństrio 1 rodzinie. Wykladzle Klemensa sprawy mazzenstwa i rodziny potraktowane są nierozłaczn1e, aczkolw1ek miecej miejsca poślęca autor problematyce maleńskiej. Z tej racji 1 winiejszym opracowaniu bęzle zaumazalna powyzsza dysproporcja, uzalezniona od rodzaju mes torlalu podanego przez naszego autora.

Podstawa zródłowa niniejszej pracy sa dzlela Klemensa Aleksandryjaklego wydanlu krytycznym 0. Stählina oraz L. Frachtela ${ }^{2}$. reksty polskie podaje przekladzle prof.J.Pliszczýnskiej ${ }^{3}$.

\section{KLEMENS OBHONCA SWIETOSCI MALZENSTWA I RODZINY}

Niepodobna zrozumieć nauk1 Klemensa o smięoścl małzenstwa 1 rodziny bez uwzglednienia historycznego kontekstu doktrynalnego czasów, których zyz 1 dzlazal nasz autor. Niezbyt ostro uswladamiany bywa lakt, to II 1 III kty heretyckie, które oxplictte lub laplictio deklaruja swa niechęc czy mogośc do mazzeństwa 1 rodziny 1 to zarómno sekty wyznajace skrajny indererentyzm etyczny, jak 1 grupy prezentujace skrajny rygoryzm moralny*. Tendencje to przyjmuja rózny stopień nasile-

2 Clemens Alexandirinus, vol. I-IV, od. 0.Stahlin, Leipzig 1905: vol. I - Protrepticus und Paedagogus/GCS 12,1936/; vol. II Stromata I-VI /GCS 15, 1 ed. 1906, 2 ed, 1936; GCS 52,3 9 d. L.Frthte1/; vo1. III - Stromata VII-VIII, Mxcorpta ax Thoodoto, Eclogae propheticae, Qu1s dives salvetur, Fragmenta, 1970; vo1. IV - Heg1ster /GCS 39,1934-1936/.

3 Klemens Aleksandryjsk1, Dywany, przakiad J.P1iszczymaka, Lublin $1972 /$ maszynop $1 \mathrm{~s} /$.

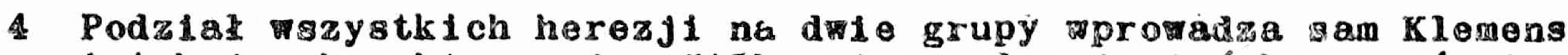
1 tak jo charakteryzuje: "Albo mięo polocaja ty bez odróntonia dobra 1 za albo odvrotnio, przeclagajac strune ponad waz-

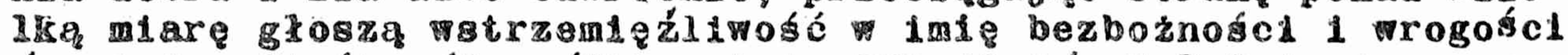
/ zg legdom Stw6roy/" - /Stromato1s III 10,2/. Bolg1and grupy wyznajace indyrorantyzm otyczny nazyma grupami "rozmazkyni": -S1 sara notato come la confutazione di clemente procoda altornando lo critiche contro un tipo di oreticl/dissoluti/per 
nia poczynajac od odrzucenta zasad wsplerających zycle małzeńskie, poprzez pośrednia negacje makzeństwa, az do wyránego potępienia mazzeństwa 1 rodziny ${ }^{5}$. W swych pismach Klemens wystepuje jako apologota odplerajacy te ataki. Stad w Jego nykładzio daje glę zauwazyć zdecydowane akcenty wynikajace z checi przeciwstamionia sie fałszywej doktrynie. Naleby wiec pokrótco przyjrzé sie tym rakszywym tezom, by zrozumiec powtarzane z naciskiem przez Klemensa ortodoksyjne zasady dotyczące instytucji matzeństwa 1 rodziny.

1. Makzeństwo ustanowione z woll Boga nie jest rozpusta lecz powołaniem do dzieła wspóttworzenia 1 doskonalenia ślata

Deprecjacja godności małzeństwa mypywa z zasad doktrynalnych przyjmowanych przez wspólnoty heterodoksyjne. W II $⿴ ., j a k$ wiadomo, wóród sekt głoszz̧cych lałszyma gnoze rozpowszechniony był antynomizm, który praktyce przejawiał sie podrzucentu calego Starego Testamentu. W konsekwencji głoszono, ze nowe prawo, które przynjós Chrystus, nle dopuszcza małzeństwa. Klemens z oburzeniem móm1 o tych, "którzy atakuja Prawo 1 mazzeństwo, jakoby było ono /tj. małzenstwo/ dozmolone tylko wedle Prawa, a nie wedle Nowego Testamentu" ${ }^{6}$. To twierdzenie heretycy próbowali udowadniac stosujac błędnq egzegezę. Na podstawie ocen 1 słów Klemensa mozna wskazać na jej pięé typów:

a/ egzegeza wykretna pologająca na "naciaganiu", tj. na proferowaniu wasnej interpretacji, często róntacej sie zasadniczo od tej, która chciaz nadá́ autor tekstu natchnionego; b/ dosłowne tłumaczenie tego, co zostało powiedzlane alegorycznie; c/ wyrymanie z kontekstu; d/ tzumaczente symboliczne; e/ trumaczenie bluźnier$\operatorname{czo}^{2}$.

venire quindi al tipo di eretici opposti/rigoristi, oncratiti, ...." /F.Bolg1an1, dz.cyt., 88/.

5 Por. F.Drączkowsk1, Niektóre tendencje 1 zasady pierwszych mspólnot heterodoksyjnych na podstaw1e "Stromatow" Klomensa Aleksandryjsk1ego, RTK 23/1976/ $\mathrm{z}_{.4}, 81$, paragraf 4. pt. "Odrzucenie 1nstytucj 1 małzeństwa 1 rodziny".

6 Stromateis III 108,2。

7 Por.F.Drączkowsk1, Niektóre tendencje 1 zasady ..., dz.cyt., $78-80$. 
Uzbrojent taka metode heretycy powołujac sie np. na słowa Chrystusa: "A ktoby nie miał nienawiści ojca, matki ani zony ani dzieci, molm uczniem być nie moze" ${ }^{8}$, twierdzili, ze wypowiedź ta świadczy o odrzucentu małzenstwa przez Chrystusa. Podobnych argumentów mozna by przytoczyć wiele. oto niektóre z nich:

- Chrystus powiedział: "dzieci tamtego świata ani się nie zenią, ani nie wychodza za mązn ${ }^{9}$;

- człowiek z przypowieści ewangelicznej, który nie przybyz na ucztę, bo pojazz zonę, jest dla nas przestrogą ${ }^{10}$;

- prorok powiedział: "Zestarzałem się wóród wszystkich moich nieprzyjacioł" /tj • małzeństwie/11;

- słowa: "Blada cięzarnym 1 karmiącym matkom w owych dniach" sa wskazówką, że nie nalezy rodzlc $c^{12}$;

- sam Pan Jezus slę nie ozenił, dajac w ten sposób przykład właściwego postępowania ${ }^{13}$.

Za pomoca poryżzych argumentów próbowano uzasadnić, dlaczego nie nalezy wstępować w zwiazki małzeńskie, przy czym nie atakowano wprost samej instytucji małzeństwa 1 rodziny. Natomiast o wiele groźniejsze były wypowiedzi, whórych heretycy posumali sie do bluźnierstwa nazywając małzeństwo rozpustą 1 dzlełem szatana. Na ten temat czytamy u Klemensa:

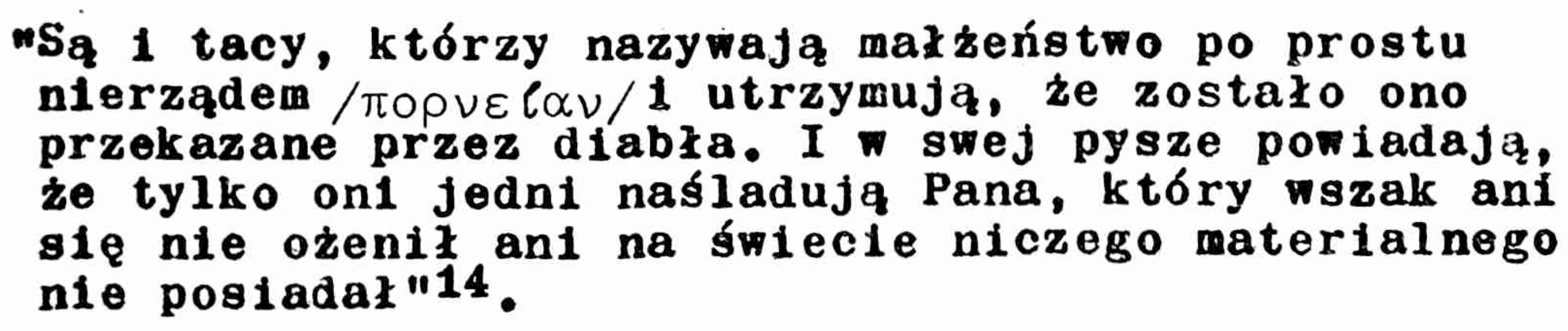

Powyżze twierdzenie zawiera ostra deprecjacje mazzenstwa 1 to dwoJaką: określente małzeństwa jako "nierząd" przesądza jego negatywna

8 Lk 14,26; por. Stromate1s III 97,2.

9 Stromateis III 87,1 ; por. Lk 20,34 .

10 Stromateis III 90,4; por. Lk 14,20.

11 Stromate1s III 90,5 ; por. Ps 6,8 .

12 Stromate1s III 49,6; por. Mt 24,19 ; Mk 13,17 ; Lk 20,35.

13 Stromate1s III $49,1-3$.

14 Tamze III 49.1; por. III $80,3$. 
kwalifikacje moralna, a powiedzenie, ze zostało ono "przekazane przez diabła", ofca wszelkiego zła,deprecjonuje małzeństwo rzo ontologioznym.

Z pozycji przeciwgtawnej godziły w swietośc matzeństwa sekty rozwlazłe, przyjmujące np., podobnte jak karpokratianie, wspólnote kobiet. Zdaniem Eplfanesa, syna 1 ucznia Karpokratesa, "Bóg wszystko bez wyjatku stworzył dla człowieka do woṕlnego uzytku 1 kobiete polączyz z męzczyzna tez dla wopólnego uzytku, podobnie ustanowiz parzente się bez róźntcy wszystkich zwierząt" ${ }^{15}$. Juz samo zestawienie laczenta sie mezczyzny 1 kobiety z parzentem sie zwierzat dograduje wspólnote pozycia seksualnego ludzi do rzędu zycia dzie. Z relacjl Klemensa dowladujemy sie, że karpokratiante organizowall uczty, konczace się zbiorowa org1ą ${ }^{16}$. Zasade swobody sycla seksualnego przyjmowall równiez ntkolaicl, antytakci, zwolennicy Prodikosa 1 bazylidianie ${ }^{17}$.

Powyzsze obyczaje, obrazające dotkliwie nie tylko godnośc mazzeństia 1 jego śwlętość, ale godzące równiez wasadę monogamicznosci 1 nierozerwalnosci małzeństwa, spotkały sie z ostrym poteplenlem ze strony Aleksandryjczyka, wyrażonym wastepujzcych ołowach:

\footnotetext{
"C1 po trzykroć nieazczęsliwi ludzie umazaja sie za Kapłanów misterium clelesnej wspólnoty milosnej 1 dopuszczaja myól, że ta wspólnota doprowadzi $1 \mathrm{ch}$ do Królestwa Bozego. Lecz tego rodzaju wapólnota prowadzi bezposrednio do domów publicznych, a towarzystwem takich ludzi moga być raczej wieprze 1 kozky; u nich moga liczyć na powodzenie tylko dziewki
}

15 Tamze III 8,1. Zestawiente źródez do sekty karpokratian podaje: T.Volker, Quelien zur Geschichte der christichen Gnosis, Tabingen 1932, 33-38.

16 Stromate1s/III 10,1/ Klemens podaje Ich następujący opis: "gromadza sie na uczty /nie nazwałbym agapa takiego 1 ch zebrania/ mezczyźni 1 koblety razem. A kiedy juz nasyca sie jedzeniem dowol1/"spozycla sytośc priywotuje K1prydę"/ - [Eurypides Irg. incert 895], jak sie to mawia, pogasimszy lampy usumaja śliatło, deriaskujące tę lch nierządną "sprawieditwość, 1 obcuja z soba cieleśnte, jak chca, z kim sobie zycza, przez tego rodzaju "agapę" uprawiająo wspólnote; co więcej juz za dnia zadaja od kobiet, od jakich im sie podoba, powolnośc1 - stosunku do prawa Karpokratesa - bo przeciez nie godzizoby się powiedzleć: "stosunku do prawa Bożego".

17 Na temat zycia tych rspólnot zob. F.Drączkorski, Niektóre tenden- 
wystające przed domami publicznymi 1 gotowe przyjać kaźdego bez wyjatku, kto by tylko miaz na nie ochotęi18.

Po przedstawieniu $i$ potepieniu błędnych pogląáw na maźenstwo 1 rodzine Klemens przechodzl do wykładu pozytywnogo. W pierwszym rzędzie odwołuje sie do argumentów z Pisma ów., potom przytacza dowód z historil, tj. tradycj1 hellenskiej, a na końcu odwołuje siz̨ do argumentów racjonalnych. Odpowiadajac na twierdzenia horetykó, określajazcych małzeństwo jako dzleło diabłá, Klemens wielokrotnie akcentuje, ze małzeństwo zostało ustanowione przez Boga. Ulubionym cytatem, do którego sie odwołuje, jest tekst z Księg1 Rodzaju 1,28: "Po czym Bóg im błogosławił, mówiąc do nich: Bádźcie płodni 1 rozmnażajcie się, abyścio zaludnili zlemię 1 uczynill ja sobio poddaną". J.P.Broudéhoux obliczył, ze passus ten cytowany jest dosłownie lub jako aluzja az 12 razy we wszystkich dziełach Klemensa ${ }^{19}$. Aleksandryjczyk z naciskien podkré́la, ze "sam Bóg pozączy kobiete z męzczyzna ${ }^{20}$, czyniac wyraźna aluzję do Księg1 Rodzaju 2, 22: "Po czym Pan Bóg z zebra, które myjałz z męzczyzny, zbudował niewiaste. A gdy ja przyprowadził do męczyzny, mezczyzna powiedzial: «Ta doplero jest kościa z molch kośl 1 ciałem z mego c1ała!》n.

Przechodzac do argumentów z Nowego Testamentu Klemens zauwaza, ze Chrystus nigdzio nie zabranial małzeństia. Interpretacja niektórych mypowiedz1 nowotestamentalnych dokonywana przez heretyków jest fałszywa. Chrystus wypowiadajac zdanie: "Dziect tamtego śwata ant s1e nie żenia ani nie wychodza za mazz" / kk 20,34/ nie zakazywaz małzenstwa "dzieciom tego świata". Interpretujac poprawnie powyzsza wypowiedź Klemens stwierdza: "Pan nie odrzuca bynajmniej małzenstwa, lecz zapobiega tylko oczektwantu clelesnych pozadań w chwili zmartrychwstania"21. Podobnie prostuje inne wykretne, a niekiedy naivne, interpretacje heretyków, których cytowanie niepomiernie powiekszyiobv

cje..., dz.cyt., rozdział I 56-68 pt. "Wspólnoty rozwiąże".

18 Stromateis III $27,5-28,1$.

19 J.P.Broudéhoux, dz. cyt., 84.

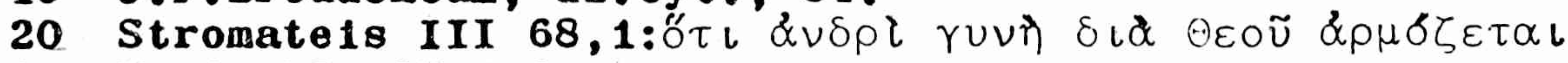

21 Tauże III $87,1-2$. 
ramy niniejszego opracowan1a ${ }^{22}$. Przechodząc do Listó Apostolskich stwierdza Klemens generalnie, ze nie ma wich wypowiedzi odrzucaJacych instytucje małzeństwa. Wszystkie listy Apostoła - pisze Klemens - pouczając o umiarkoraniu 1 powściągliwości, zawieraja niezliczone rskazówki na temat małzeństwa, płodzenia dzieci, zarządu domem, nigdzie nie odrzucają umlarkowanego małzeństwan23. Natomiast mozna by mskazać na mypowiedz1, które wręcz zalecają małzeństwo, jak chociażby ta: "Lepiej bowiem wstąpić w związek małzeński niż płonąc ządzą" 24 ,

Broniąc instytucji małzeństwa Klemens sięga równiez do argumentu z tradycji helleńskiej wykazując, ze od czasów bardzo zamierzchłych małzeństwo cieszyło sie wielka czcia 1 powazanien. Natomiast stan bezzenny w niektórych prawodawstwach traktowany był negatywnie. Na przykład: "prawodawca lacedemoński wyznaczył karę nie tylko za bezzenność, ale także za nieprawnie zawarte małżeństwo, oraz za późne małzeństro, ponadto za programowe życie w samotności"25. Po tej samej linil idzie propozycja Platona, który co prawda nie przemiduje kary za bezzeństwo, ale "kaźe temu, który się uchyliz od małzeństwa zobowizzać sie wobec skarbu państwa do ponoszenia kozztó utrzymania jednej kobiety, a sumę należna za zwiazzane z tym wydatk1 przekazywać rządcom paŕstwan ${ }^{26}$.

Wreszcie osobną grupe stanowi argumentacja, którą moźna by okreslić Jako fllozoficzno-teologiczna czy tez racjonalną. Klemens

22 Tamze III $80,2-90,5 ; 94,1-109,2$. Klemens podaje kolejno poprawna interpretacje tekstow Pisma św. dotyczacych małzeństwa: Rz 7,4 ; Mt 6,19.24; 2 Kor 11,3; Ef 4,24; 1 Kor 7,1; Lk 14,26; Iz $56,3.4$; Jor 20,14; Job 16,3 ; Ps 50,5 .

23 Stromate1s III 86,1 .

24 Tamze III 97,1 ; por. 1 Kor 7,9 .

25 Stromate1s II 141,4. Por. Ioannes Stobajos, "Anthologium" Nachsmuth-Hense/ IV 22,16; lub "Florilegtum" 67,16/Me1nek/: Ariston - "Prawo Spartiatów wyznacza kary: pierwsza za bezzoństwo, drugą - za późne małzeństwo, trzecit 1 najwi éksza - za niezgodne z prawem małzeństwo:" Plutarch w "Moral iach", w artykulo: "0 m1 zosc1 do potomstwa" /p. 493 B/ wspomina o prawach przeciw bezzeńetwu oraz późnozeństiu, powołując slę na Likurga 1 Solona.

26 Stromate18 II 141,5; por. Platon, Prawa VI p.744 P. 
wychodzi z załozenla, ze "wszelki twór Boga jest dobryn27. Człowiek, koronujacy całe dzieło stworzenia, jest dobry 1 to dobry w tej formie, jakiz Bóg mu z natury udzieliz. Zatem "sama natura uczyn1ła nas skłonnymi do małzeństwa, jak to wynika ze struktury fizycznej męzczyzny i kobiety oraz ze świadectwa: «owocujcie 1 mnózcie się "28. Bóg-stwórca całego świata zaprosił człowieka do wspófpracy dziele stwarzania. Małzonkowie wydajac na swiat 1 mychowujac potomstwo kontynuujaz Boski proces tworzenta 1 rozmijania świata. Zatem "instytucja małzeństwa pomocna jest dziełu stworzenia"29. Klemens sadzi, ze "nalezy sięzenić/.../ również po to, by doprowadzić świat do maksymalnej doskonałości miare naszych sil"30. Małżonkowie wiec podniesieni sa do niezwykłej rang1 1 godności współtwórców Boskiego dzieła stworzenia. Ci więc, którzy odrzucaja małżeństwo przeciwstawiaja się samemu Bogu. "Jest to wręcz bezbożne - pisze klemens - gdyz tacy ludzie niszczą boskie dzieło stworzenian31. Heretycy wykazuja brak zrozumienia dla wielkiego powołanta, jakie Bóg stawia przed małzeństwem 1 rodziną, nio rozumiejaz, ze "rozwiazłośc 1 małzeństwo nie majzz soba niczego wspólnego, podobnie Jak daleko jest diabeł od Bogan32. Dlatego Klemens z naciskiem stwierdza: "Jeśli ktoś ośluiell sį́ nazwać małzeństwo rozpusta, to rychło z powrotem popada w bluźnierstwo przeciw Prawu 1 przeciw Panum33.

Klemens bronląc małzeństwa i rodziny jbala bluźniercze twierdzenia heretyków 1 udowadnia, ze małzeństwo jest instytucją zgodną z ludzka natura, ustanowiona przez Boga od poczatku swiata, aprobowana przez Chrystusa $i$ apostołów, Instytucją, która ma swoja wielowiek owa tradycję 1 weryfikacje. Niezwykła godnośc 1 ranga małzeństwa wypływa z jego powołania do współpracy Boskim dziele stwarzania i doskonalenia świata.

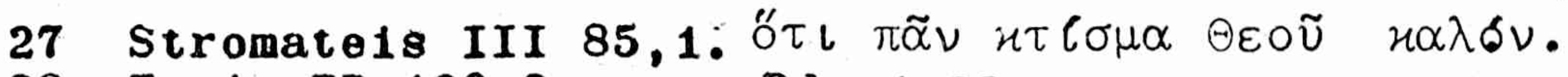

28 Tamże II 139,3; por. Fdz 1,28.

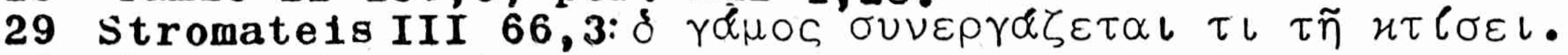

30 Tamze II 140,1 .

31 Tamze II 141,5 .

32 Tamze III 84,4 .

33 Tamże III 89.1. 
2. Pożycie małzeńskie nie uwłacza godności człowieka, jest święe 1 błogosławione przez Pana

Dotkliwym uderzeniem w zasadę pozycia małżéskiego były poglądy głoszone przez sekty manicheizujace ${ }^{34}$. Z punktu widzenta antropologicznego, tendencje te wyrazaly sie przyjęclem poglądu - czésolonym stworzentu ciała ludzkiego przez Boga, czéścionym przez Złego Ducha. Klemens z oburzeniem pisze:

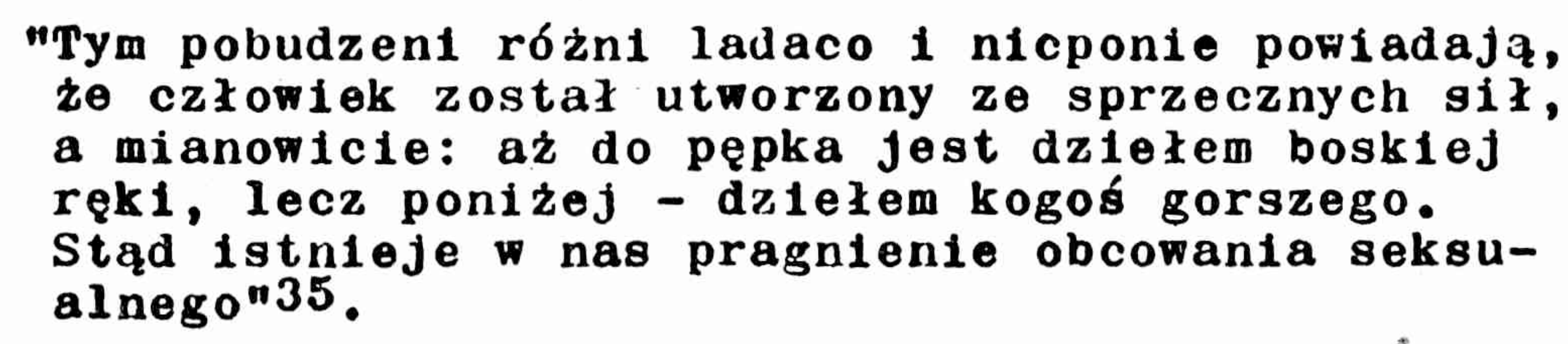

Ta dyskredytacja ontologiczna narzadó płciowych, jako niestworzonych przez Boga, stała w oczywistej sprzecznosc1 z całym porzadk1em natury. Heretycy byl1 głusi na wszelk1e argumenty. Dokec1, ktorych reprezentowal Juliusz Kasjan ${ }^{36}$, z uporem wołal1:

"Niech nikt nie opowiada, jakoby spółkowante płciowe zostało ustanowione przez Boga, niby wnioskujac z tego, ze mamy takie czésci ciała, iz kobieta wen sposób jest zbudowana, a męzczyzna inaczej, mianowicio kobieta do przyjmowanta a méczyzna do wprowadzania wia nasienian37.

34 Nie chodzi tu o mpływ manicheizmu historycznego, ktory jest późnlejszy w stosunku do czasów Klemensa /Manes zy 1 w latach 216-274/277. Por. H.-Ch.Puech, Mani, LThK VI 1351-1352/ lecz o pewne tendencje wystepujace juz wI w. po Chr., któro swoje szerokie rozwiniecie znalaziy w doktrynie Manesa. Por. H.-Ch. Puooh, Man1ch\&1smus, Man1chder, LThK VI 1352-1355.

35 Stromate18 III 34,1 .

36 Jul1usz Kasjan, załozyciel sekty kasjanitów, uczé́ gnostyka Falentyna, ok. $170 \mathrm{r}$. przebywał Egipcie, by najzarliwszym przedstawicielem enkratytów, załozycielem 1 scholarchą sekty doketów. Por. H.ilahner, Julius Cassianus, LThK V 1206; A.G11Ime1er, Doket1smus, LThK III 470-471.

37 Stromate1s III 91,1 . 
Kasjan za Marcjonem ${ }^{38}$ Walentynem ${ }^{39}$ uważał, ze wopółzycie płclowe ubliza godności ludzkiej, twierdząc, ze kczłowlek stał slę podobny do bydląt przystępując do zespolenia się we dwojen40. Klemens podchwytuje natychmiast wypowiedź Kasjana 1 odpowiada: tak rzeczywiście się dzleje, ale nie w wyadku poźycia małzonków, lecz doplero wtedy, gdy człowlek "naprawdę zechce wejść do cudzego łoza w porywie zadzy, to wtedy istotnie tak 1 człowiek ulega zbydleceniu" ${ }^{41}$. Wodług niektórych heretyków pozycie seksualno nie zostało ustanowione przez Boga lecz przekazane przez Szatana-Węza pierwszym rodzlcom $w$ raju. Na to Klemens odpowiada:

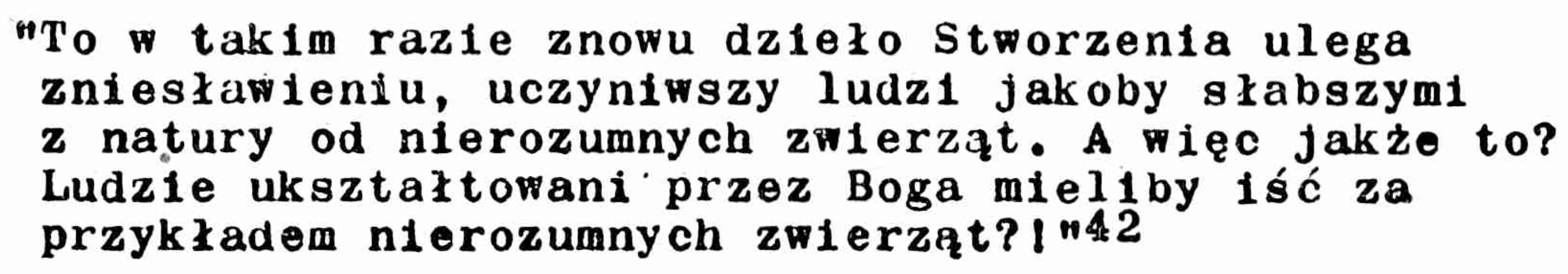

Powyzsze tezy heretycy wzmacniali dodatkowymi argumentami względnej wartośc1. Zwolennicy Kasjana powoływall się np. na wypowiedzi zaczerpnięte z apokryficznej Ewangeli1 do Egipcjan 43 , w których rzekomo zawarty był postulat odrzucenia róźnicy płci w Imiez źle rozumianej ascezy. Klemens cytuje następującą wypowiedź Kasjana: "Gdy Salome dopytywała sie, kiedy begdzie wiadome to, czego usiłowała się dowiedziec, rzekł Pan: gdy podepczocio stopami zasłonę wotydlłwośc1, a męski pierwlastek z żéskim nie będzie ani męski ani zeński"44. Powyższe słowa, które rzekomo miał wypowiedzieć

38 Marcjon, twórca sekty marcjonitów, ur.w r. 80 Synopie/Pont/, zmar w 160 r., syn biskupa z Synopy. Por. H.Rahner, Markion, LThK VII 92-93.

39 Walentyn, gnostyk, twórca sekty walentynianów, w latach $135 / 110$ przybywa do Rzynu; ok. $160 \mathrm{r}$. udał sio prawdopodobnie na Cypr. Por. P.-Th.Camelot, Valent1nos, LThK X 602.

40 Stromate1s 102,3; por. Ps 48,21: "Człowlek, co w dostatku źyje, ale sie nie zastanawia, przyrómnany jest do bydią, które giną".

41 Stromateis $102,3$.

42 Tamzo 102,4 .

43 Bangelia do Egipcjan powstała prawdopodobnie $⿴$. poI. II . jako ewangelia chrześcijan eglpskich. Uzymal1 jej heretycy: JuIlan Kasjan, Toodot uczer Walentyna, sabelianie 1 naaserczycy. Klemens, który cytuje ja wielokrotinie, nie zalicza jej do ewangel11 kanonicznych, ale tez nie potepia jako heretyckiej, co czyni Orygenes. Por. Apokryfy Nowego Testamentu I, pod red.M.Starowieysk1ego, Lublin 1980,85-86. 
Carystus, miakyby implicite zawiorac wskazbwke do poniechania pobycia płciowego w ogóle.

Do tego dołączano toz racje moralno-ascetyczno, twierdząc, to pozyc1e seksualne jest elementem negatywnym, ograniczajacym wolnoś ludzka, czy tez czynnikiem uniemozliwiającym kontakt z Bogiem w modlitwio. Stąd przyjmowano zasade calkowitej wstrzemiezliwosci płciomej jako głómay postulat doskonalenia chrzescijarskiego. Znamiennym przykładem tym względz1e sa opin1e gloszono przez Tacjana Syryjczyka, który bazując na wyketnej egzegezie wypowiedzi fw.Pama z Plerwszogo Listu do Koryntian $/ 7,5 /$ twiordzil - swym dziele "O doskonalentu slę redług Zbawlciela", ze mgoda obopólna na powściągliwośc /domyślnie seksualną/ umozliwia modlitwe,

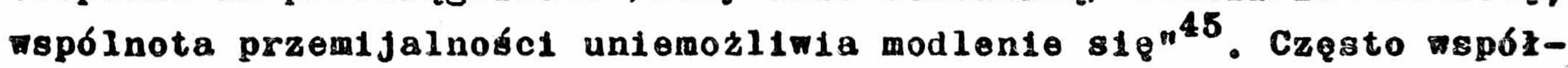
tycio plciowe stawlano jednym rzędzie z błedami 1 grzechazi. Rspomniany my zoj Juliusz Kasjan sadz1士, zo Chrystus mybariz nas nie tylko od zł̣a, ale równiez od wspózzycia seksualnego. Na ten temat tak sle pyowiada: "Jak można nie uznawać zbawiclela za przyczynę sprawczą śwlata, jeśli nas przomienił, uwolnił od błǫdu 1 od zwiazku seksualnogo czéśc1 ciała męskich 1 zeńsk1ch? 46

F odpotiedz1 Klemens sprowadza sagdy heretyk6w do paradoksu: jośl mazieństwo jest czyó nleczystym, to onl sami sa tez nioczyśc1. "Utrzymuja /heretycy/ mianowicle, ze pspólnota mazzenska jest czymó nieczystym" - pisze Klemens - "a sami wszak aøbj byt wziel1 z tej mspólnoty - jakzo wiqc moga sami nie czué sie splamien1? ${ }^{47}$ Nastepnie przechodzi do argumentow z Pisma sw., cytujac êkgt proroka Izajasza: "Mol wybrant nio beja sio trudzté nadaremnto ani płodzlé dziecl na przekieństwo, gdyz nasienie jest pobiogosłamione przez Pana ${ }^{43}$. Rozumomanio Kiemensa zdaje sie byc tego rodzaju:

\section{Tamie III 81,1 . \\ 46 Tamze III $92,1$. \\ 47 Tamze III 46,5 .}

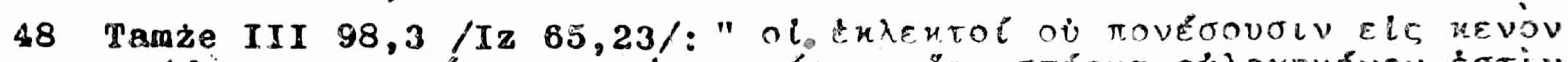

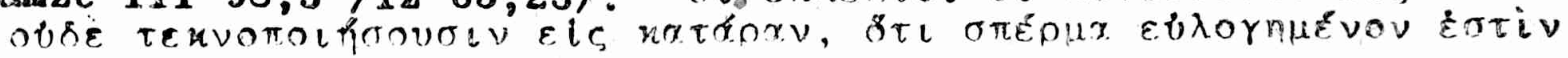

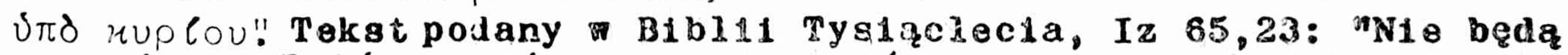
s1e trudzić na prózno an1 płodzis dzloci na zgubę, bo plemieniem błogosiawionych przez Pana sa ont sami 1 potonkowie ich wraz z nimi". 
jeśli nasienie grḱ małzeńskie tych, którzy należa do Chrystusa, tj. wybranych ol f $\lambda \varepsilon-$ utol jest przez Boga zaaprobowane 1 błogosławione. Za powyzszą zaś Interpretacją Klemensa przemawia następująca wypowiedź:

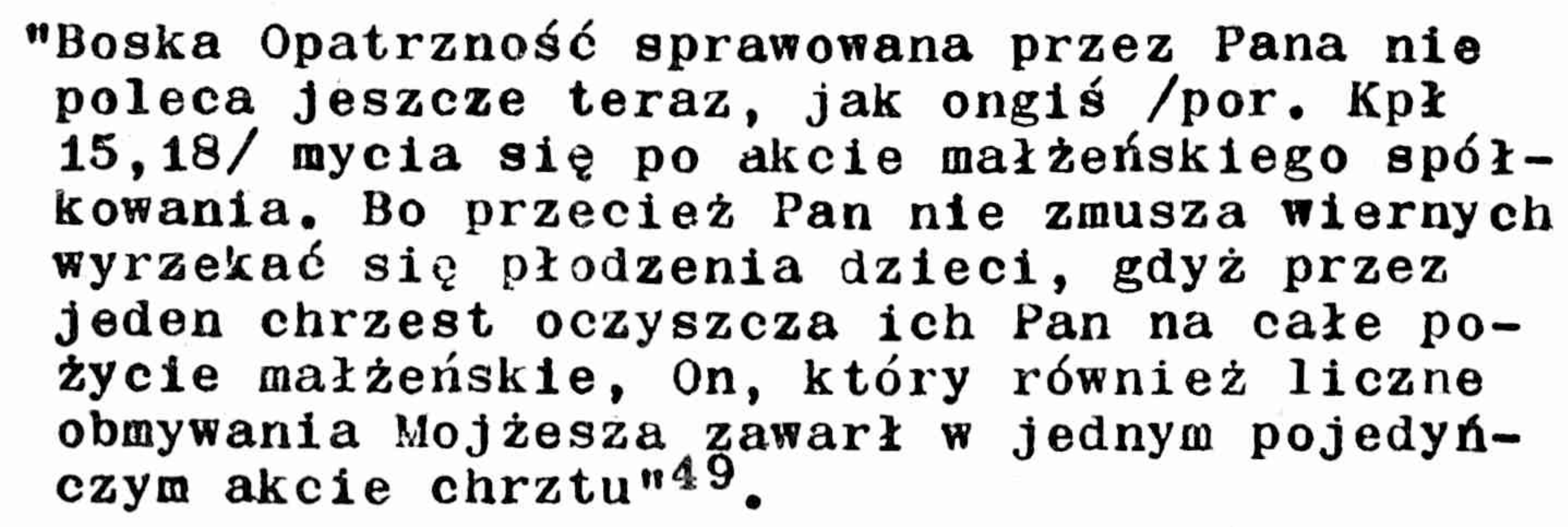

Oczyszczenie dokonuje się przez obmycie. Chrzest jest obmyciem uwalniający od w3zystk1ch zmaz 1 grzechów. Jest również wszczepieniem w Chrystusa, a poprzez Chrystusa w zycie Trójcy Słiętej, wszczepienien dającym uświęcenie. Małżonkowie, trwający we mpólnocie życia z Chrystusem sa czyści i śrięci. Stąd ich pozycie małzenskie jest czyste $i$ święte. Dlatego też Klemens posuwa sie aż do stwierdzenia: "Tych, którzy zostall uświęceni, myślę że nasienie jest śrięte" ${ }^{50}$. Na uwage zasługuje odcień warunkowy, jakim zostało powiedziane powyższe zdanie, mianowicie zwrot "tych, którzy zostali uświęceni" wskazuje, ze nie każde pozycie seksualne jest błogosławione przez Boga, lecz tylko zwi qzek tych, którzy uświęceni zostali przez chrzest chrystusowy, tylko tych "śwlęte jest nasienie" 1 błogosławione współzycie seksualne. Cała argumentacja sekt heterodoksyjnych prowadziła do potępienia i odrzucenia aktu seksualnego jako uwłaczającego godności człowieka, pochodzącego od szatana, więc niezgodnego z wolą Bozą. Heretycy widzieli wile rozrodczej element ograniczajacy wolność chrześcijanina, uniemożliwiajacy prawdziwy kontakt z Bogiem wod11twie. Klemens zb1je te twierdzenia wskazując na ich bluźnlerczy charakter z racji przeciwstawlenia sie boskiemu dziełu stworzenia. Pozycie małzorków obmytych 1 uświęconych przez chrzest jest święte i błogosławione przez Boga.

49 Stromateis III 82,6 .

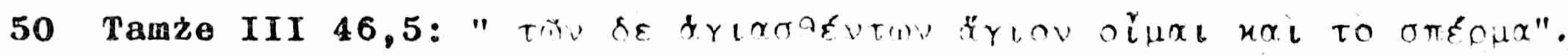


3. Narodziny, uświęcone przez narodzenie Chrystusa, nie sa oszustwem szatana

Potępiente przez sekty heretyckie płodzenia dzieci i narodzin są logicznaz konsekwencją dwóch wcześniej omówionych tendencj1, tj. potępienia małzeństwa 1 pozycia seksualnego. Z dzisiejszego punktu widzenia te trzy tendencje moga wyaawać się co najmniej dziwne, lecz w czasach Klemensa stanowiły poważne niebezpieczeństwo godzac w podstawowa komórke Kościoła, Jaka jest małzeństwo i rodzina. Trudno rozstrzygnąć, czy u genezy tych tendencji stoi zła wola czy nadgorliwość, dość że heretycy w uzasadnieniu powyżsych tendencji stale powoływali sie na autorytet Pisma św. 51 Klemens z oburzenien odrzuca fałszyma egzegezę wypowiedzi Pawłowych, dokonywana przez Jullusza Kasjana, gdy pisze:

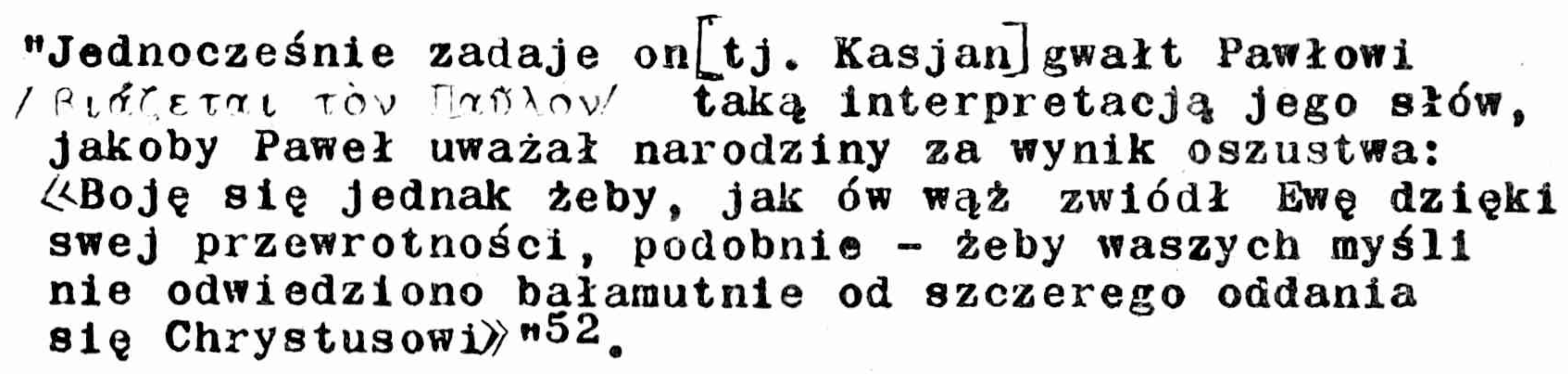

Podobnych przykładów wykrętnej egzegezy, przy pomocy których próbowano udowodnić, ze narodziny są mynikiea oszustwa Szatana, moźna by przytoczyé wiele. Często zadziwia nas pomysłowość herêyków /hazujących najczłściej na egzegezie alegorycznej/polegajżca na sztucznym docsepianiu wasnej interpretacji do słów jednoznacznie wskazującyci na inny sens. Typowy przykład takiej egzegezy, stosowanej przez heretykóm, cytuje Klemens Aleksandryjski:

51 W równym stopniu odwoływaly sie do autorytetu Pisma \$ٔ́. sekty rozwiazłe, jak i skrajnie ascetyczne. Por. J.P.Broudehoux dz.cyt., 61: "L"Ecriture est mise à profit pour justifier ausi bien l'immoralité que l'ascétisme le plus rigoureux".

52 Stromate1s III 94,1 ; por. 2 Kor 11,3 . 


\begin{abstract}
"Riektórzy jednak traktuja powołanie do zycia jako coś przemijającejo 1 przeznaczonego do

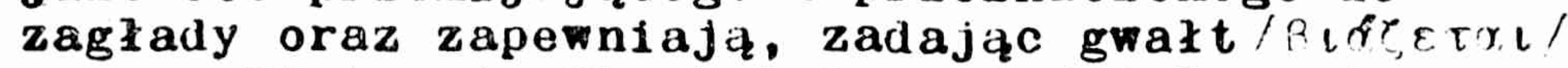
samemu Pismu, że Zbawiciel powiedzial, mając na myśli płodzenie dzleci: dzić zadnych skarbów na ziemi, gdzie mól i raza niszczą szystko〉》53.
\end{abstract}

Na tak naiwna 1 naciggana interpretacje Klemens daje natychmiast ซraściwe wyjaśnienie:
"Zbawiciel nie wypowiedział tych słóm, myślac - sprawie płodzenia dzieci, lecz do szczodre- go dziolonia sie z innymi zachęcajac tych, którzy chca tylko gromadzić nadmiar bogactwa, a potrzebującym udzielać pomocy nie chç" 154.

Wyszukiwantu pseudoargumentów heretycy nie ograniczali sie tylko do ksiag kanonicznych Plsma śm., lecz siegali toz do apokryI6 i renomowanych dziel filozofil 1 literatury helleńskiej, stosujac zansze wykrętna lub naciaganz interpretacje. Uzasadniajac odrzucenio płodzenia potomstwa powolywali sie, m.in., na nastepuJąca wypowiedź Chrystusa, który rzekomo miał powiedzieć: "Przyby-

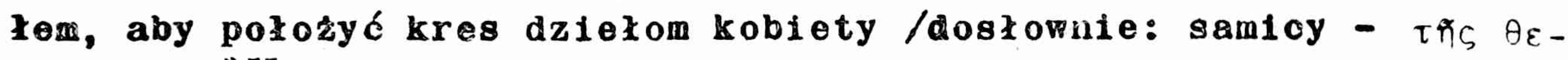

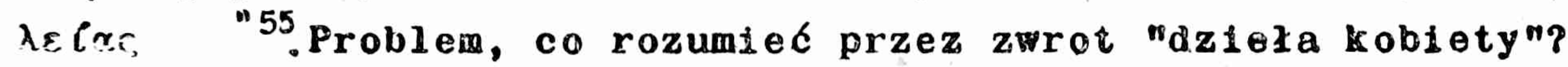

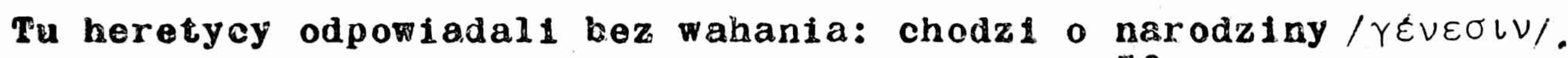
wodobny sposob traktowano wypowicdzi Platona 56.

odpowiedzi Klemens myazuje, ze twlerdzenta heretyków sa - sumie bluźnlercze 1 prowadza konsekmencjl do szeregu paradoksóv:

\footnotetext{
"Jesll same narodziny sa czyms ziym, to powinni tez bluźniercy uznać ze Pan uczestmiczacy narodzinach uwiklat sie w zio. oraz ze Najślietsza Dziewica, która Pana urodzila, téz uwilkala sie tzło?! Biada mi,
}

53 Stromateis III 86,3 ; por. Mt 6,13 .

54 Stromateis III 86,4 .

55 Tanze III 63,2. Słowa wypow1edziane do Salome "Ewangel1i do Egipcjan".

56 Stromateis III 18,3; por. Platon, Fedon p.60B; Politeja I p.328D. 
lle tu zła! Bluźnią przeciw woll Boga 1 misterium Stworzenia śriata ci, którzy spotwarzaja narodziny"57; "Wszak narodziny są dzielem Stworzenia, a jest to stworzenie swiata przez Wszechwładcę, który przeciez nie sprowadzałby z lepszego bytu do gorszegons.

Chrystus Pan uczestnicząc w narodzinach uświęcił je tym samym 1 nobilitował. Jego bowiem przyjście na świat, przez narodzenie z Maryi Dzlewicy, zapoczątkowało cały szereg wspaniałych dziez Bożych. Swiadomy tej prawdy Aleksandryjczyk woła retorycznym uniesieniu:

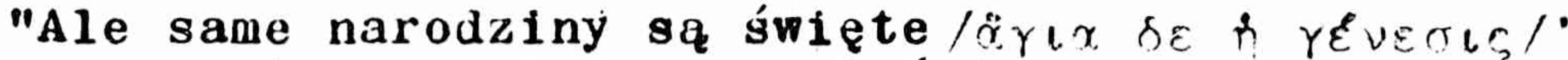 przez nie przeciez powstal świat, przez nie - istoty żye, przez nie - dzieła wszelkiej na- tury, przez nie - anlołowie, przez nie - po- tęgi, przez nie - dusze, przez nie - przy'iaza- nia, przez nie - Prawo, przez nie - Ewangelia, przez nie poznanie Boga samego"59.

Bez narodzin Chrystusa nie byłoby Kościoła.

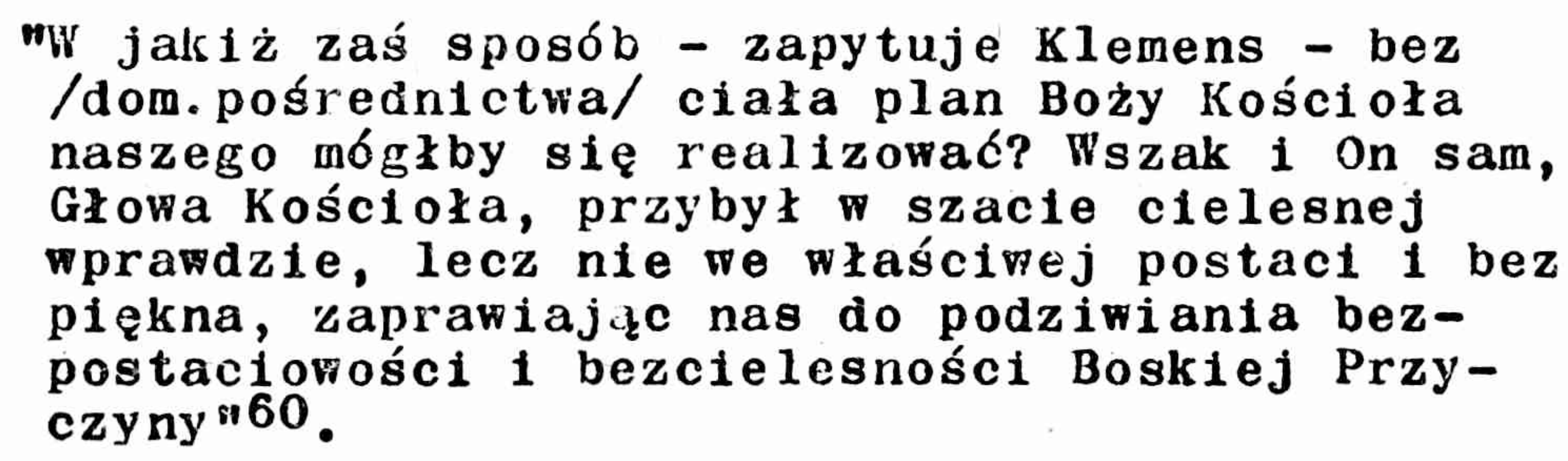

Przeciwstawiając się instytucji małzeństwa 1 pożyciu małżeńskiemu heretycy konsekwentnie odrzucal1 tez płodzenie potomstwa 1 narodz1ny, twierdząc, ze są one wynikiem oszustwa Szatana. Ich argumentacja nie opierała sie na zadnej liczacej się bazie źródłowej. Klemens sprowadzając do paradoksu 1ch twierdzenia udowadniał, zo narodziny są święte, zgodne z wolą Bożą, uśrięcone przez samego Jezusa Chrystusa, który wich uczestni-

\footnotetext{
57 Stromateis III $102,1-2$; por. III 90,5 .

58 Tamze III 94,2 .

59 Tamze III 103,1 .

60 Tamże III 103,3; por. EP 1,22; 5,23; Iz 53,3.
} 
czyz. W planach Opatrzności Bozej maja one stanowić kontynuacje dzieza stworzenia.

\section{KLEMENS PROKLAMATOREM SWIETOSCI MALŻENSTWA I RODZINY}

Ataki heretyk 6 ma instytucje małzenstwa 1 rodziny z jednej strony zmusizy poniekęd Klemensa do odparcia błędnych twierdzeń, z drugiej natomiast - do pozytywnego wykładu ortodoksyjnoj nauki na ten temat. Co wiecej, herezje stały sie bezpośrednim bodźcem do jasnego 1 wyraźnego wyakcentowania podstawowych prawd 1 zasad regulujących zycie małzeńskie 1 rodzinne. W tym sensie mozna by nawet mớć o pozytywnym mpłyie polemik1 antyheretyckiej na myśl Klemensa ${ }^{61}$, który nie poprzestaje na odparciu ataków heretyckich, ale rozlicznych miejscach swego wykładu mocno eksponuje tezy przeciwstawne. Stąd nteustannie akcentuje czystość, wzniosłośc i śfięość instytucjl małzeństwa i rodziny oraz przytacza niezliczone wypowledzi autoró śwlecklch 1 kościelnych potwierdzajace te opinie. konsekwencji znajdujeny nauce Aleksandryjczyka zdocy dowane dowartościowante instytucjl małzeństwa 1 rodziny. Słusznio zauwazy Broudéhaux, ze jest to novum witeraturze chrześcijańskiej: Klemens staje sle nie tylko obrońca, lecz 1 proklamatorem bwletośc1 małzeństwa 1 rodzlny ${ }^{62}$. Nauka Klemensa w tym zakresie zasługuje równiez na uwage z tego wględu, ze jest on plerwszym po św. Pawle autorem ortodoksyjnym, który szczegółowo zają się problemami mazzeństwa 1 rodziny 63 .

61 Por, J.P.Broudéhaux, dz.cyţ., 60: "A divers t1tres donc la polemique a eu sur la pensee de clément une influence bénéI1que".

62 Tamż 83: "Lorsque clément porte une appréciation sur le marlage. L...l. Falt nouveau dans la littérature chrétienne, nous voyons notre auteur proclamer la salnteté du mariage".

63 Tamze 7: "Après saint Paul, clément apparaît dans la littérature chretienne orthodoxe comme le premier auteur qui ait prété une attention soutenne aux problemes posés par le mariage, la virginité, les rapports familiaux". 
1. Zródła świętośc1 małzeństwa i rodziny

a/ Chrzest - mozczepiente w życie Boze. Klemens syntetycznie przedstawia źródła 1 program uświęcenia małzeństwa 1 rodziny w słowach:

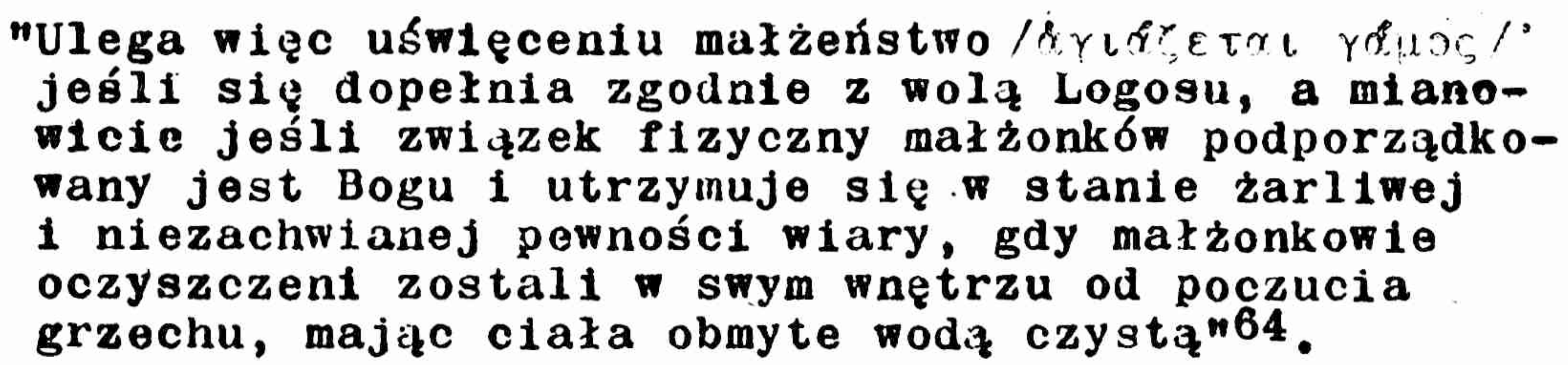

Ostatnia częś powyzszej wypowiedzi dotyczy chrztu, szczególnie zaś jego Punkcji oczyszczającej 1 uwalniającej od grzechu. Wcześniej cytoralismy wypowiedź, gdzie niedwuznacznie Klemens przedstawiał chrzest jako źródło oczyszczenta małzonków, w słowach: "przez jeden chrzest oczyszcza lch Pan na cało pozycie małzeńskie, On, który liczne obmywania Mojzesza zawar $w$ Jednym pojedynczym akcie chrztun 65 .

Chrzest, obok wyzej wymlenionego działania, sprowadza szereg ważnych skutków:

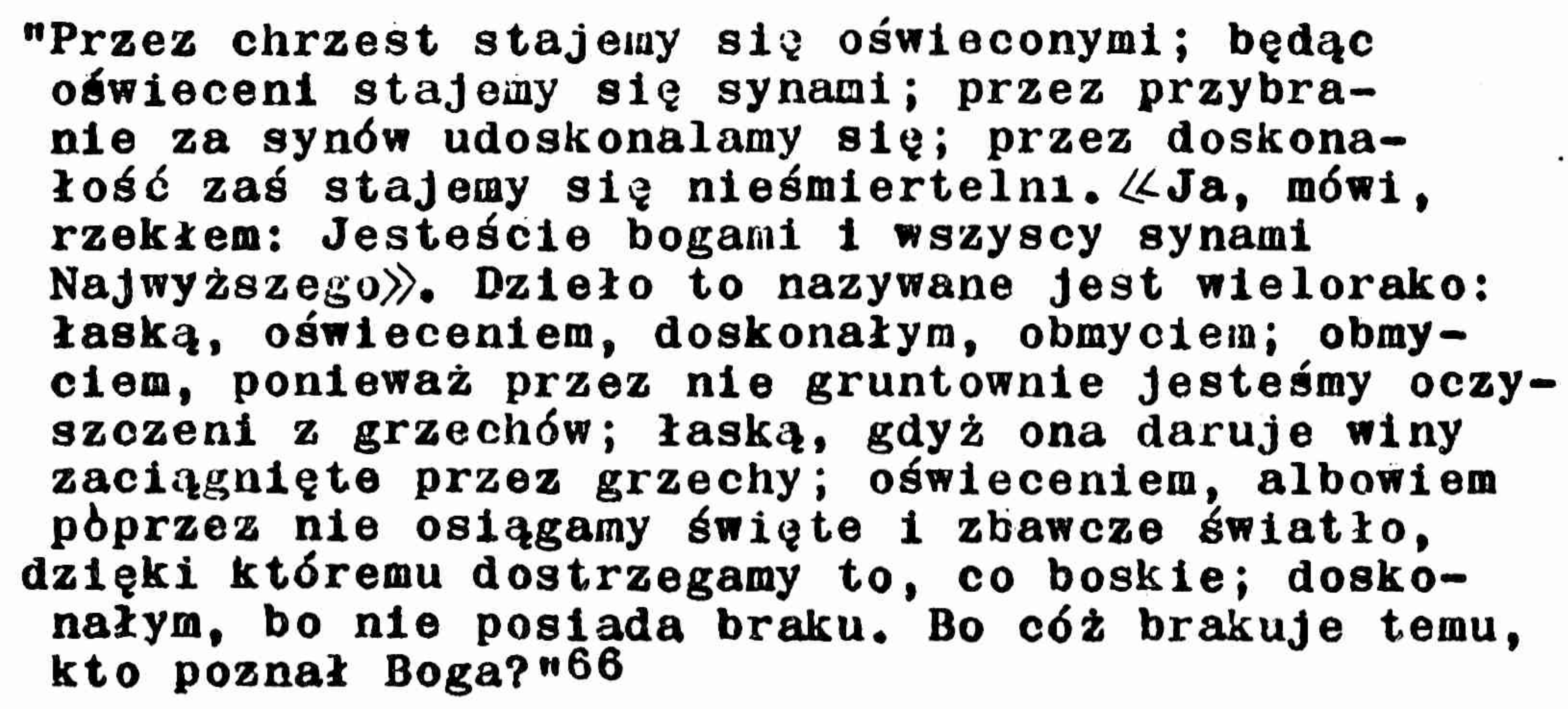

Przez chrzest otrzymujemy:

64 Stromateis IV 126,1 ; por. 1 Tym 4,5 .

65 Strouateis III 82,6 .

66 Paidagogos I 26,1-3; por. Ps 81,6; 2 Kor 4,4; Tt 3,5; Rz 6,23; Jk 1,17. Wszystkie teksty z pierwszej ksiegi"Pedagogan cytuje w przekładzle ks. Tadeusza Putona/Pedagog - Ksiega I Klemensa Aleksandryjskiego, Lublin 1977, mps. BKUL/. 


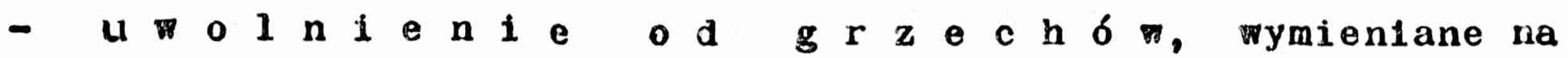
plerwszym miejscu, poniewaź "uwolnienie od grzechów jest początki@m zbawionia"67;

- d a $r$ an 1 e 1 n zaciagnietych przez grzechy;

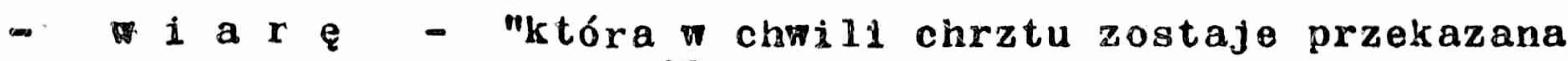
przez Ducha Swiętego"68;

- osw 1 e e n 1 e, czyli "świqte 1 zbawcze światło, dzięi któremu dostrzegamy to, co Boskie";

- $\quad$ p $\quad$ z y b r a n 1 e za s y n 6 w;

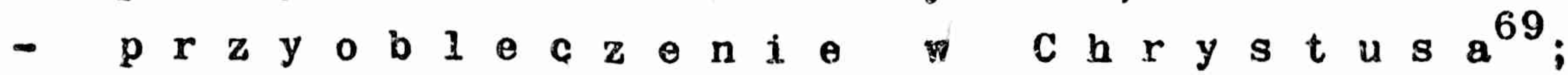

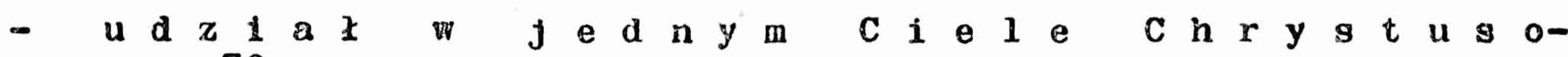
w $\mathrm{m}^{70}$;

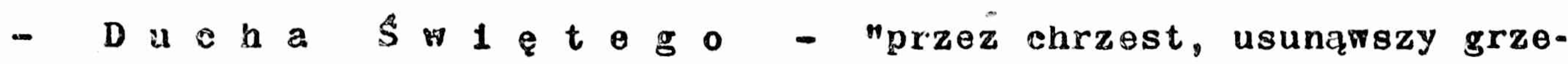
chy, które jako chmury przyémiewaja Ducha Bozego, mamy wolne, bez źadnej przeszkody 1 wyraźne oczy Ducha, dz1ęki którym doetrzegamy tylko to, co jest bożego, poniewaz Duch Swięy przychodzący z nieba rozlewa sie na nas" 71 .

Uczestnikami tych wszystkich dóbr staja się maizonkowie oczyszczeni i ubogaceni łaską chrztu, a ich zwiazek "ulega uświęceniug 72 .

b/ Obecność Boga w małżenstwie i rodzinie. Owocem chrztu jest udzial w jednym Ciele Chrystusowym, tj. udział w Bosko-ludzkiej wspólnocie zycia, jakaz tworzy Chrystus Bóg w Trójcy Jedyny 1 lud Bozy ${ }^{73}$. Chrzest jest wię wazczepienien do tej wspólnoty zycia Bożego, jest wszczepienien whrystusa, czy teź przyobleczeniera się Chrystusa. Klemens powtórzy za paw

"Bo wy wszyscy, którzy zostaliścle ochrzczenz

Chrystusie, przyoblekliście sie Chrystusa.

87 Paidagogos I 26,3; por. I 29,5; I 50,4.

68 Tamże I 30,2 .

69 Tamie I 31,1 .

70 Tanzo I 31,2 ; por. Ga $3,26-28$; 1 Kor 12,13 .

71 Paidagogos I $28,1$.

72 Stromateis IV 129,4 .

73 F.Drączkowski, Kościót - Agape według Kleqensa Aleksandryjsk1ego, Lublin 1983, 131-133. 
Nie ma juz żyda ani poganina, nie ma niewolnika ant czlowieka wolnego, nie ma juz męczyzny, ani kobioty, wozyscy bowiem jesteście kimś jednym w Chrystusie Jezusie"74.

Małzonkowie wszczepieni poprzez chrzest w Chrystusa sa w N1m obecni a On wich. Bóg więc jest obecny małżéstwie przez Jezusa Chrystusa. Klemens prawde te bardzo jasno wyraz1 w słowach:

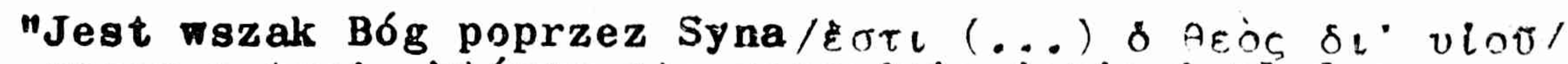
razem z tymi, którzy się rozsądnie zeniz i płodzaz dziecj małzeństwie, jest tenże sam, w ten sam sposób Bóg, i z tym, który w sposób dorzeczny przestrzega powściagliwości"75.
}

Swoje stwierdzenle popiera Klemens cytatem z Plsmá św., który interpretuje alegorycznie. Komentując słowa Chrystusa: "Bo gdzle sa dwaj albo trzej zebrani imię moje, tam jestem pośród nich" /Mt 18,20/, p1sze: "Kimze zaś są ci dwaj lub trzej zebrani w imię Chrystusa, pośród których jest Pan? Czyż nie rozumiał przez tych trzech mężzyzny, kobiety i dziecka? Bo przeciez kobieta połaczona została $z$ mężzyznaz z woli Bozejn76.

Klemens postuluje, by matżonkowie swiadomie budowal1 wych domach atmosferę waniosłej religijności, przepojonej czystościa, duchem modlitwy 1 bojaźni Bożej oraz śwladomościa zycia z Chrystusem 1 w Chrystusie stale obecnym wóród nich. Program takiego życia przedstawia następujących słowach:

\footnotetext{
"Należy więc strzec czystości małzeństwa podobnie Jak chronić od zmazy święty wizerunek, budząc si z Panem, 1d丸̨c na spoczynek ze słowami dzlękczynienia 1 z modiltwa na ustach: Czy to gdy spać się kładziesz, 〈czy gdy święte światło sie uniesie 〉, przez całe nasze zycie biorąc Pana na éwladka, majac pv sercu bojaźń Bożą, a umiarkowanie stosując 1 do cjałan77.
}

74 Paldagogos I 31, 1; por. Ga 2,26-28.

75 Stromateis III 68,4 .

76 Tamze III 68,1; por. Rdz 2,22.

77 Stromateis II 145, 1; por. Hezjod, Prace i dnie, 339. 
2. Realizacja programu uświęcanta małzenstwie 1 rodzinte

Cały program uświęcania małzeństwa streszcza sie w trzech

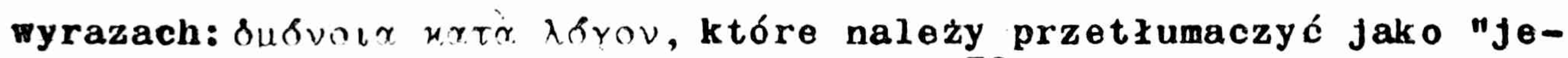

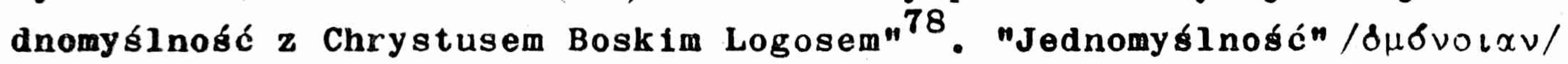
należy rozumieć szeroko,jako zgodę czy zgodność, tak w aspekcie teoretycznym, Jak 1 praktycznym, tj. jako zgodnośc z zasadam1 Boskiej nauki Chrystusa oraz zgodność z Jego wola. Weześniej cytowaliśmy wypowiedź, wtórej Klemens wyraźnie akcentował, ze "małzeństwo uśmięca się, jeśli dopełnia się zgodnie z wola Logosu/rat’́

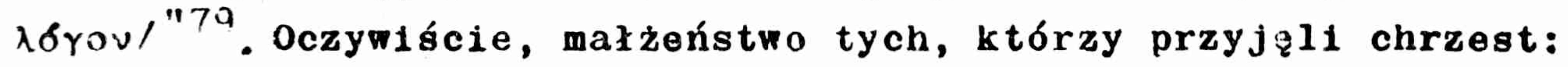

"Mäzeństwo ludzi przeciętnych uzyskuje jednomyślnośc tylko wakresie doznawania rozkoszy, natomiast małzeństuo chrześcijan 80 wiedzio do jednomyślnośc1

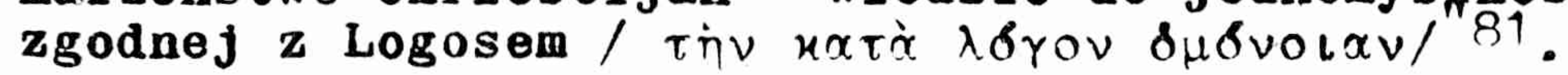

Dążc więc do uświęcania małzeństwa 1 rodziny nalezy najpierw usunąc z niego wszystko to, co jest niezgodne z Chrystusen; następnie zaszczepiać 1 rozwijać to, co prowadzi do jednomýs lności z Nim. W praktyce mozna te dwa procesy określić jako odrzucente zła 1 dazzenie do cnoty.

a/ Odrzucenie zła. Odnośnie do czystośc1 pozycia małzenskiego Klemens deklaruje następującą zasadę ogólną:

"Nalezy usunąe z pozycia małzeńskiego wszystko, czego praktykowante brudzi 1 hańb1 zwiazek, zeby nam nie zarzucano, iz parzente sie zwierząt nierozumnych bardziej odpowiada naturze, wakresie uzgodnionego juź celu, niz spółkoranie ludz1 1 82 .

78 Stromateis II 143,1; III 71,1 ; IV 126,1; por. F.Bolg1an1, dz.cyt., 70 .

79 Stromateis IV 126,1. W tym kuntekście $\lambda$ broc oznacza Chrystusa. Por. F.Bolglani, dz.cyt., 70.

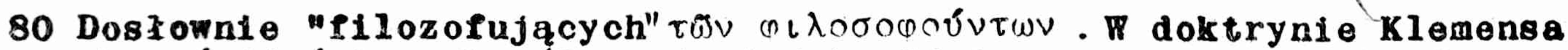
chrześcijaństwo określane jest jako "filozofla prawdziwa". Por. Stromateis I 32,$4 ; 90,1$.

81 Stromateis II 143,1 .

82 Tamie II 143,3 . 
Zeby lepiej zrozumleć sens słów naszego autora, co nodpowiada naturze "zakresie uzgodnionego juz celu", warto przypomieć podana przez niego ogólna definicje małzeństwa: "Małzeństwo jest związkiem mlędzy męzczyzną a kobietą, pierwszym hierarchicznie, opartym na prawie płodzenia prawowitego potomstwa"83. Zatem prokreacja 1 wzglad na jej skuteczność jest czynnikiem limitującym pozycie małzeńskie. w tym zakresie Klemens jest nieustępliwy 1 w dzisiejszym odczuciu, skrajnie rygorystyczny. jego opinii pozycie małzeńskio, wykluczające z góry potomstwo, jest "zniewazaniem naturyn84. ModyPlkując wyzej podaną definicje małżéstwa Klemens powie wprost: "Małzeństwo jest pragnieniew płodzenia dzieci"85. Dopuszczalne jest tylko to poźcie małzeńskie, które ma na celu spłodzenie potomstwa:

\footnotetext{
"Prawo mymagało od męzczyzn powściągliwego współzycia ż żonami i tylko dla spłodzenia

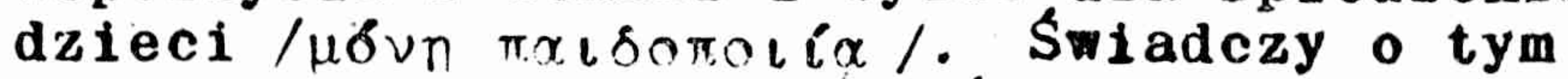
zakaz naty chmiastowego spółkowania człowieka niezonatego z branka wojennz"86 ... "Pisino bowiem toleruje wszelkie zwi zzki seksualne tylko ze wgledu na poczęcie potomstwan87. "A wyrażenia,z powodu waszej niewstrzemięzliwości / $/ 1$ kor $7,5 \%$ uży nie stosunku do tych, którzy sposób powécizgliwy korzystaja $z$ małzeństwa ze wzgledu na płodzenie dzieci, lecz w stosunku do tych, którzy pragna wyjść Juz poza samo płodzenie dzieci"88.
}

Z tej racji wykluczal też wyraźnie onanizm małzeński ${ }^{89}$ oraz ostro potęplal pederastie $i$ wszelkie zwiazki przeciw naturze 90 .

83 Tamże II 137,1; por. F.Bolg1ani, dz.cyt., 66.

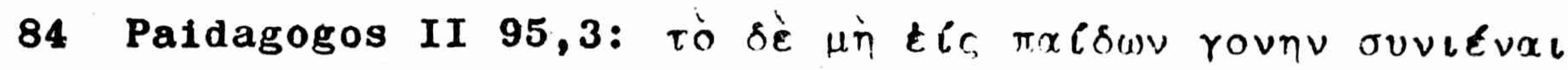

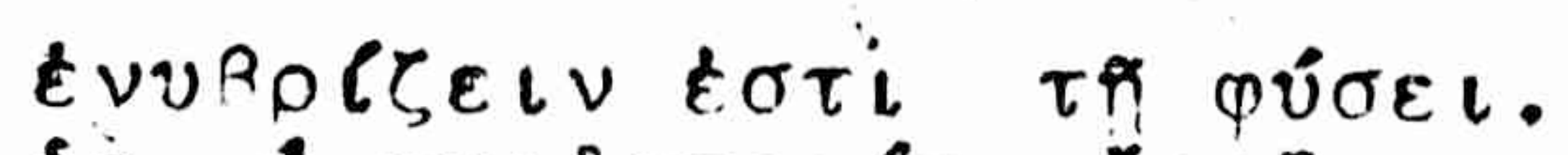

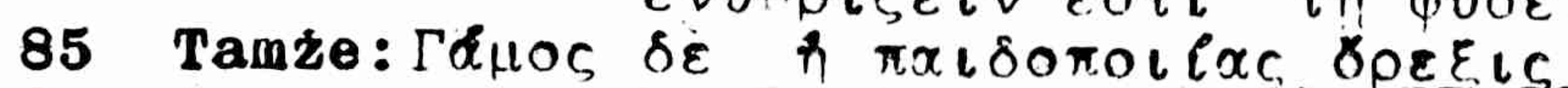

86 Stromateis III 71,4; por. tamze II 88,4-89,2; Pp 21,11-13.

87 Stromate1s II 88,4 ; por. tamze III 89,2 .

88 Tamze III 96,2.

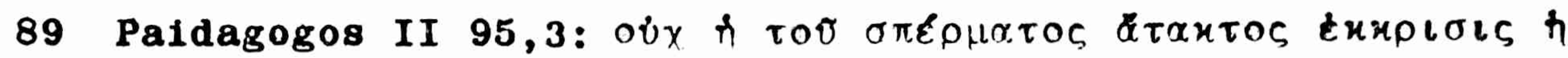

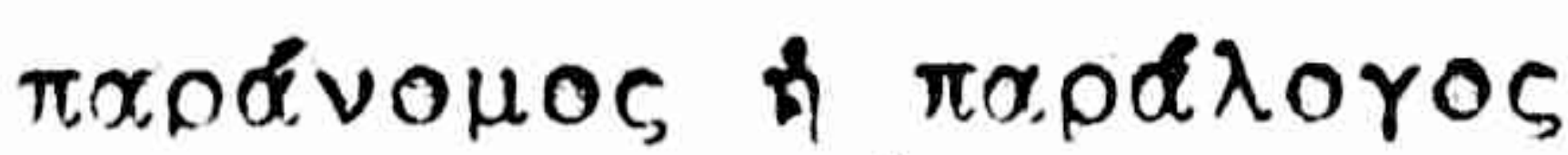

90 Tamze II 87,3. Szereg szczegółowych przepisów na temat pozycia małzeńskiego zamieszcza Klemens w dziesiątýn rozdziale ksiegi II "Pedagoga"; por. J.P.Broudéhoux, dz.cyt., 7 . 
Praktyczná konsekwencja powyższych założé jest zasada okresowej wstrzemięźliwości w pożyciu małżéskim. Dotyczy to okresu ciazzy i karmienta niemowlęcia:

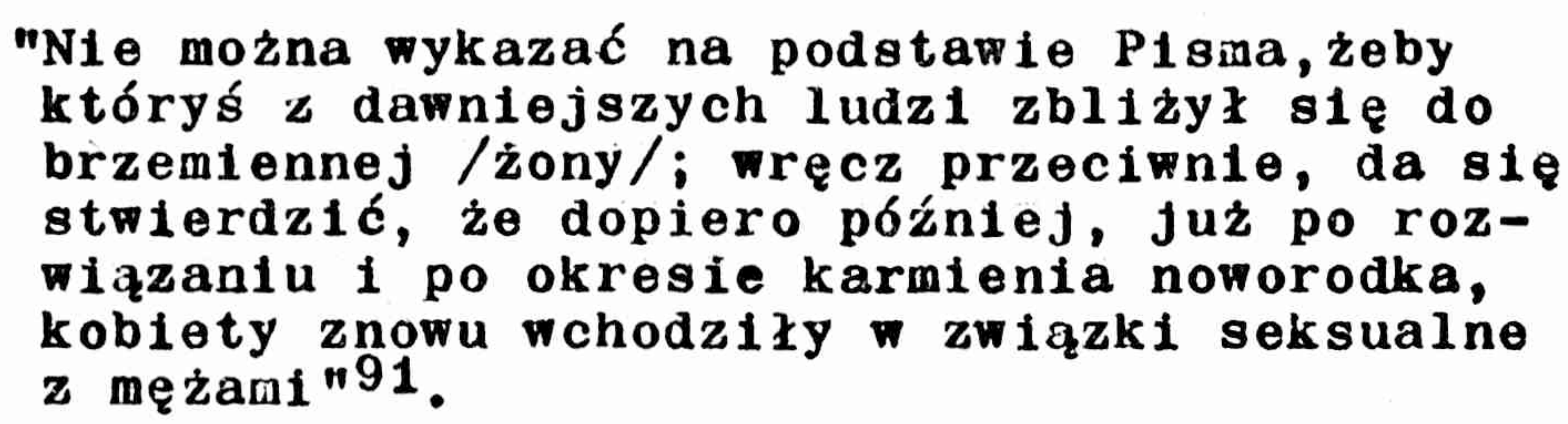

Przerwa pożyciu małzeńskim moze nastąpić również ze względów religijnych. W takim wypadku jednak wymagana jest zgoda obu małzonków, co Klemens bardzo mocno akcentuje, mając na uwadze jedność i trwałość zwiazku małżeńskiego. Intorpretując zaś wypowiedź 6w. Pawła z Pierwszego Listu do Koryntian $/ 7,5 /$ pisał:

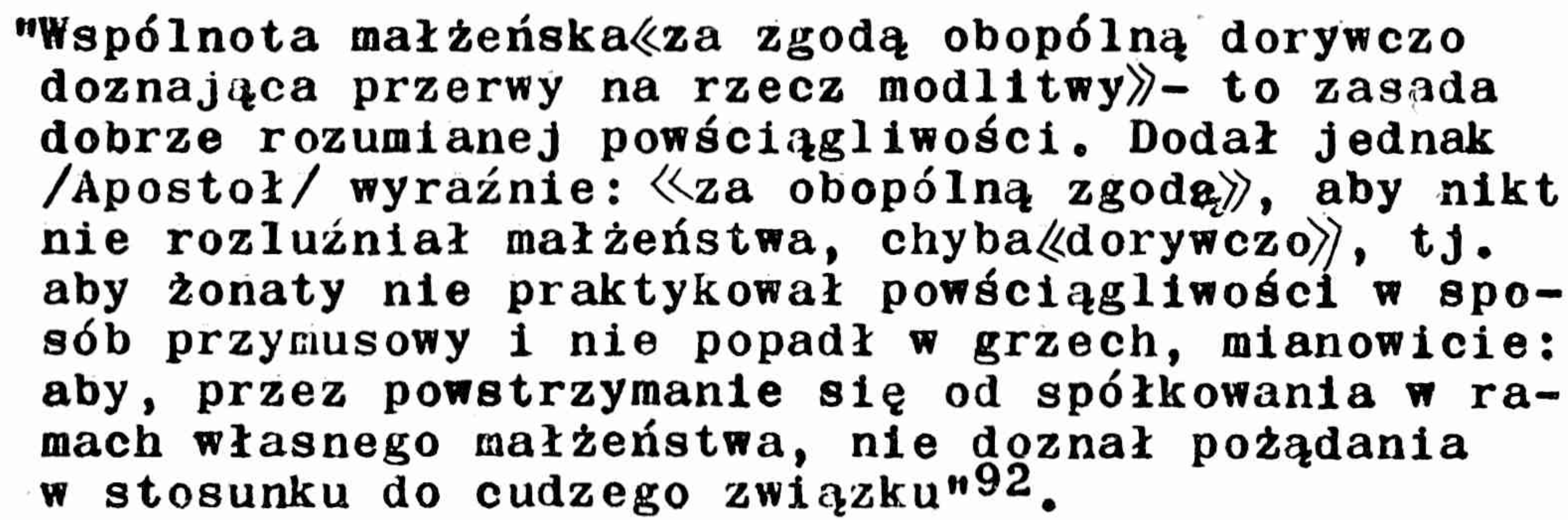

Przerwa w pozyciu małzeńskim ma pomóc małzonkom w wyzbyciu się postawy poządliwości. Zdaniem Klenensa namiętność, na skutek upływu czasu, ulega wymianie na rozsądne pragnienie ${ }^{93}$. Klemens eksponuje zasadę pełnego partnerstwa w pozyciu małzeńskim. Jest za równouprawnieniem kobiet ${ }^{94}$. Postuluje, by kobieta z miłości łączyła się z męzczyzną: "żeby kochała nie z przymusu albo koniecznośc1 męzczyzn̨̨, który ją kocha"95. Staje w obronie godnośc1 kobiety, kiedy przypomina, ze Prawo Chrystusowe "wzbranta mezczyznom

91 Stromate18 III 72,1 ; por. tamze III 72,4 .

92 Tamze III 79,1 .

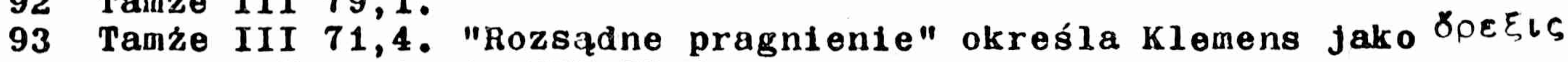

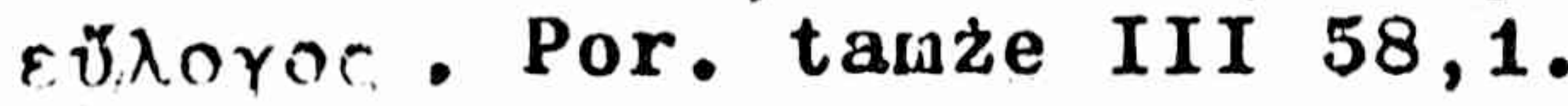

94 Por. Stromate1s IV 59,2-67,4.

95 Tanże II 137,4 . 
traktowania żony jako miłośnicy 1 za cel stawiá sobie nadużyoie zmysł owe n $^{96}$.

Broniąc integralności małzeństwa 1 rodziny zdecydowanie odrzuca i potępia zabijanie nte narodzonych dziect:

\begin{abstract}
"Ale ludzkiego dziecka usunięcie jakiez znajdzie usprawledliwienie? Haczej w ogóle nie powinien sie zenté ten, kto chce nie posiadać potomstwa, niżby z nieumiarkowariego poządanıa rozkoszy miaz się stać dzieciobójcą"ğ7.
\end{abstract}

Kto z góry ryklucza potomstwo nie powinien sięzenić:

"jeśl1 komuś wychowanie dzieci wydaje sie przykre, Jako odciagajazce od słuzby Bozej, z powodu potrzebnych do wychowania zajęć, a nie znosi łatwo zycia samotnego, nie powinien tylko z tego ostatniego powodu pozadac małzeństwa"98.

Małzonkowie dążąc do świętości, tj. do "jednomyślności" z Chrystusem, winni odrzucic wszelki grzech 1 zło, przede wszystkim wszelka mý́l o cudzołóstwie oraz to mszystko, co mogłoby naruszyé trwałość Ich wspólnoty małzeńskiej 1 rodzinnej. W tym względzie widzi Klemens niezastąpioną role kobiety. Za św.Pawłem sądzi, ze "kobiety starsze powinny zachować postawe godną, nie dopuszczac się oszczerstw, nie popadać wiewole pijaństwa"100:

\footnotetext{
"N1enarazona na oszczerstwo czyni kobietę tylko szlachetny umiar w upiększaniu się 1 zdobientu, gotowość do zarliwej modlitwy błagalnej, unikanie częstej nieobecności w domu, uchylante się, o ile to mozliwe, nawet od spojrzenia w strone ludzi spoza kręgu jej rodziny 101 ieksza dbałość o dom niz niewczesne plotkowanie"101.
}

96 Tamze II 143,1 .

97 Tamze II 93,1; Klemens twierdzi, że Prawo Starego Testamentu chroniąc cięzarne samice zwierząt uczy szacunku do poczętego zycia ludzkiego. Na ten temat zob. F.Draczkowski, Wychowawcza funkcja Prawa Starego Testamentu woncepcji Klemensa Aleksandryjsk1ego, iTK 26/1979/ z.3, 17-30.

98 Stromate1s III $67,1$.

99 Tamze II 134,4 ; II 145,3 ; II 146,2 ; III 47,2 ; III 89,1 ; IV 126,1

100 Tamze IV 128, 1; por. Tt 2,3-5.

101 Stromate1s II 146,1; por. 1 Tyın 5,5; 5,13. 
Małzeństwo pragnące podporządkować się Bogu winno, zdaniem Klemensa, odrzucić od pozycia małzeńskiego nszystko to, co przeciwstawia się prawom natury 1 prawom Boskim, przyjąć zasade nionaruszalności poczętego życia, usunąć grzech 1 wszystkie wady, które niszcząc ich Jednomyślność z Chrystusem, niszcza toz ich wspólnote małzenska i rodzinną.

\section{b/ Dazenie do cnoty, W pierwszej księdze "Pedagoga" /101,2/} podaje Klemens nastąpujaca definicję cnoty: "Cnota jest dyspozycją

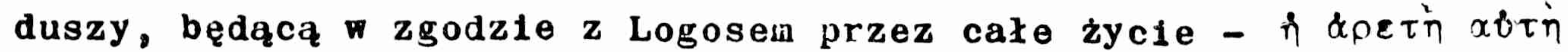

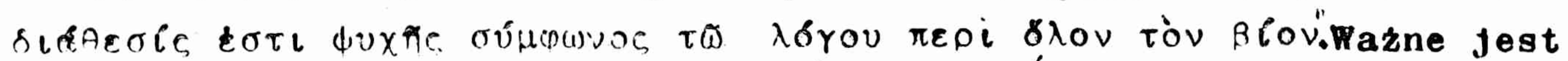

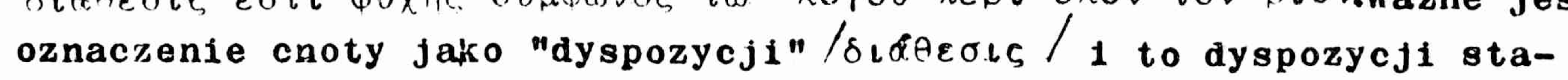
zej, bo trwajacej "przez całe zycie". Istota tej dyspozycj1 - to

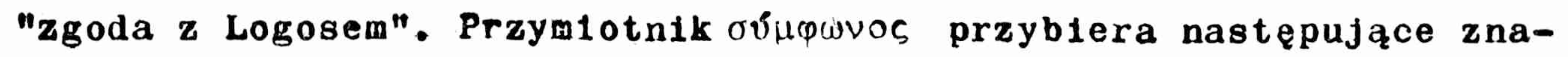
czenia: 1. zgodnie dźwi żczący, harmonijny; 2. jednobrzmiący; 3. mówiący ta sama mora; 4. proporcjonalny, harmonijny; 5. zgodny, przyjazny 102. Wcześniej powiedzieliśmy, ze dążenie do świętości polega

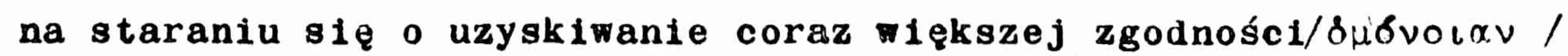
z Boskim Logosem Chrystusem. Innymi słowy dazenie do śrietości mozna określić tez jako dązenie do cnoty. Dążente to jest procesem określanyu równiez jako stałe upodobnianie siéf ofolwols do Boga 103 realizowane procesio kształcenta 1 wychowania chrześcijańskiego ${ }^{104}$. $T$ sumie, dazzenie do cnoty nalezy rozumieć jako dęzenie do uzyskania coraz wiekszej "jednomyślności", czy tez "zgodności" z Chrystusem Boskim Logosem. Ta zaś, jest źródłem szczęścia małzeńskiego. Dlato-

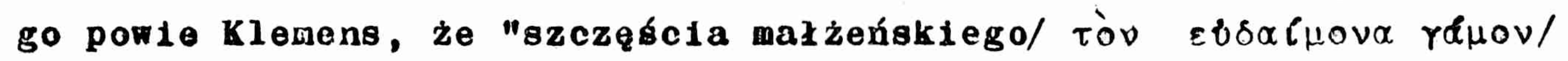
nie naleźy oceniać miarą bogactwa ani miara piękna, lecz cnoty

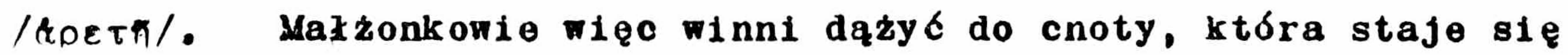
źródłem $1 \mathrm{ch}$ szczęścia.

102 Por. Słownik grecko-polsk1, pod red. Z.Abramow1czómny, Farszawa 1965, IV 176.

103 Stromateis II $136,5-6$; IV 28,1; VI 77,5. Na ten temat pisze F.Baravalle, Il concetto di "Homolosis Theo" in Clemente Alessandrino, Torino 1952.

104 F.Drączkowski, Kościót - Agape ..., dz.cyt., 79-82.

105 Stromate1s IV 126,2. Mamy tu przykład przeszczepienia zasady stolckiej na grunt chrzescijańsk1; por. Musonius, Re11. p.69,6. 
Miłoość_chrześćJańska lagage L. Określana przez Klemensa

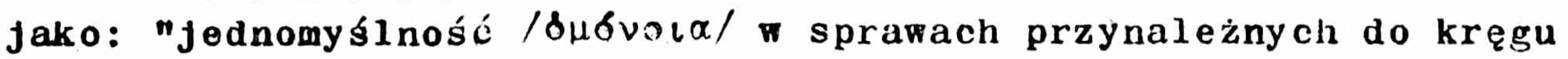
intelektualnego, egzystencjalnego 1 moral nego, albo, krótko mówiazc, wspólnota życia / rolviulla $A$ Cov/ Agape w kontekście innych wartości zajinuje nadrzędne i naczelne miejsce oraz odgrywa centralną rolę w systemie wartości przyjętych przez Klemensa Aleksandryjskiego ${ }^{107}$. Nie jest ona jedna z wielu cnót, lecz ich sumz i streszczeniem. Za św.Pawłem powie klemens, ze agape jest najwi ęszą z wszystkich cnót"108. Obejmuje całego człowieka, tj. wszystkie jego sfery: intelektualną, moralną 1 egzystencjalną. Skierowana jest całkowicle na Boga, który jest jej źródłem 1 celem ${ }^{109}$. Agape jest Jedna. Jej przedmiotem jest Bóg i całe jego dzieło stworzenia, któnre wienczy człowiek ${ }^{110}$.

Małzonkowie winni przede wszystkim z całych sił dążyć do miłości doskonałej Boga, przedkładając ja ponad wszystkie inne wartośc1. Dlatego 'ani dzieci, ani małżeństwa, ani rodziców nie stawia doskonały chrześcijanin wyzej od miłośc1 Boga oraz od sprawiedliwości wyclu"111. Nie znaczy to wcale, by chrześcijanin miał lekcewazyc swoje małzeństwo 1 rodzinę. Wręcz przeciwnie, Klemens eksponuje ideał łączenia miłości Boga z miłośc1a do swego domu. Doskonały chrześcijanin bowiem:

"prawdziwym mężczyzną ukazuje się nie przez wybór dLa sieble zycia samotnego, lecz «tym zwyciezza męzów), 1z troszczįc się o małzeństwo, płodzente dzieci oraz opieke nad domem jednoczésnie nie wykazuje wrażiwości ani na rozkosz, ani na ból. Mimo kłopotów o dom, nie daje oderwać sie od miłośc1 Boga, zwycięsko wychodząc z wozelkiej

106 Stromate1s II 41,2. Por. F.Drazczkonsk1, Agape pismach Klemonsa Aleksandryjskiego, Pelplin-Lublin 1980.

107 Por. W. V81ker, Der wahre Gnostiker nach Klemens Alexandrinus, Berlin 1952, 502; 0.Prunet, La morale de Clément d'Alexandrie ot 10 Nouveau Testament, Par18 1966, 117.

108 Stromate1s IV 54,1; por. 1 Kor 13,13.

109 Stromateis VI 104,1; por. tamże V 13,2; F.Drączkowsk1, Kośció - Agape, dz.cyt., 115 .

110 Tamze 93 ; por. Stromateis II 86,7 ; IV 43,2; V 19,4; VI 75,3; 113,4 .

111 Tamże VI 100.2. 
próby, na jaka tylko wystawia go sytuacja ojca rodziny, męza, pana słuźby 1 właściciela majątkun112 ... "Dlatego czy jedząc, czy p1jąc, czy pełniąc Punkcje małzeńskie, jesili rozum tego wymaga, a nawet śniąc obrazy senne, zawsze postępuje 1 mýll w sposób swięty. Dlatego jest w tym stopniu czysty, ze zawsze moze się modlićn113.

To samo dotyczy żony, która powinna:

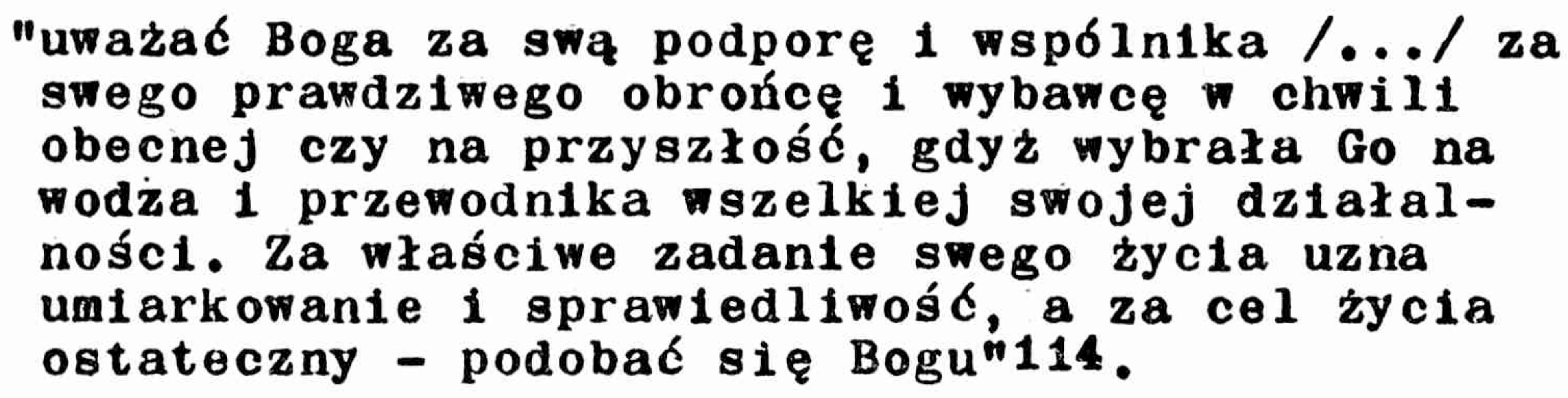

Miłość Boga, wraktyce źycia codziennego, nie koliduje - zdaniem Klemensa - z miłościa małzeńska. Co do tego ośmiela sie nawet polemizować ze św. Pawłem pisząc:
"Apostoł rzecze:《człowiek bezzenny troszczy sie o sprawy Pana; żonaty natomiast troszczy sie o to jak podobać się swojej zonie). A dla- czego tak? Nie jest to mozliwe dla nich zboznie podobać się swym żonom, a jednocześnie wyrażać dzięccynienie Bogul A czyż nie jest dozwolone zeby człowiek zonaty razem ze swa towarzyszka zycia troszczył się o sprawy Pana?"115

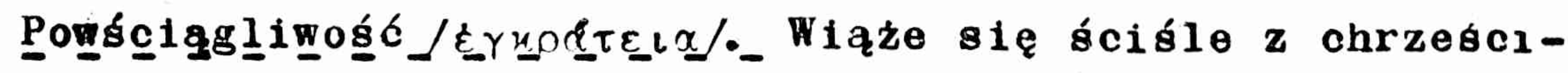
jańska agape. Jej zadantem bowiem jest niejako oczyszczente drogi dla miłości chrześcijańskiej. Wskazuje na to juz sama jej definicja:

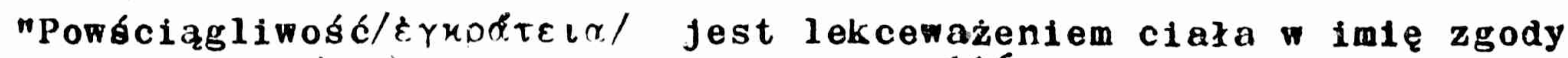

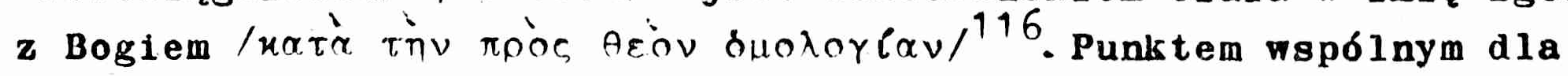
obu cnót jest "zgoda z Bog1em", określana raz jako "homonoia" innym razem jako "homologia"117. o ile agape ma dazyc do rozwijania

112 Tamże VII 70,7 ; por. Stromateis VI 64,2 .

113 Tamźe VII 78,5 .

114 Tanze IV 127,2.

115 Tauze III 88,2.

116 Tamze III 4,1 .

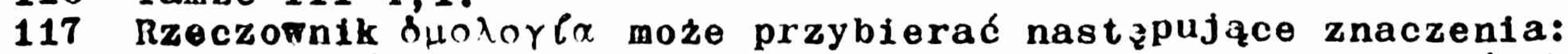

1. zgodność; 2. zgoda, ustępstwo; 3. ugoda. umowa; 4. ślub, 
jednomyślnośc1/zgody/z Bogiem, o tyle powściagliwość ma likwidomać przoszkody ze strony ciała, mogace hamować ten proces. Jej zakres rozumie Klemens bardzo szeroko. Powściagliwośc bowiem dotyczy nie tylko pragnioń seksualnych, ale równieź innych niewłaściwych poządań, które są udziałem duszy nie umiejącej się ograniczýc do zaspokojenta potrzeb tylko niezbędnych ${ }^{118}$. Powściagliwość moze się wiqc odnosís do Języka, do stanu posiadania, do uźmania czegoś $i$ do poząania. Uczy nie tylko umiarkowania, choć uzycza nam takze umiarkowania, bę-

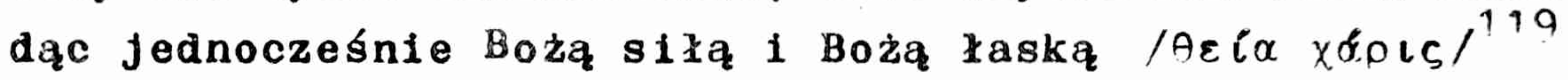

"Powściagliwoś jest pogarda pieniazdza, lekcewa-
zeniem rozpusty posiadania /ponętnych/ widokón,
okiełzaniem jęzka. panowantem nad zyyi myśla-
mi"120.

Jest ogromna róźnica między powściągliwościz propagowanaz przez róże szkoły ellozoficzne a tą, którą głosi chrzescijaństwo:

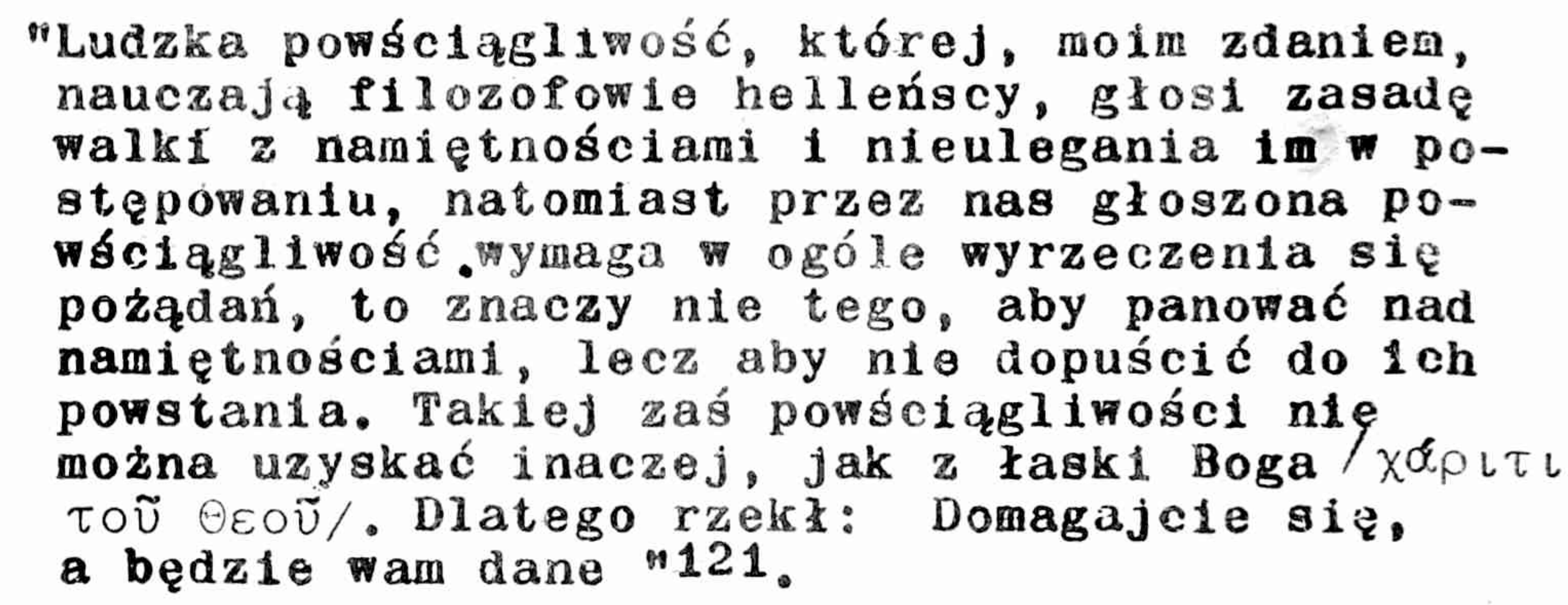

Cwiczente się cnocie powślagliwości jest szczególnte mazne dia zachowania czystości i gouności pozycla małzeńskiego, a obowiażek ten równym stopniu dotyczy męza i żony:

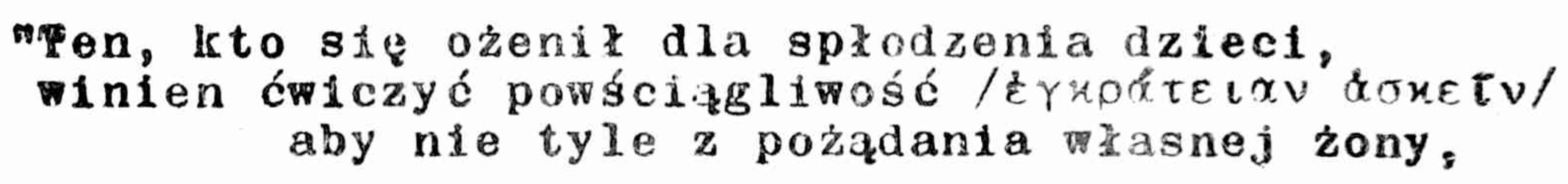

\$lubowanle; por. Skownik grecko-polsk1, pod red.Z.Abramowiczómny, Warszawa 1962, III 281 .

118 พpły Arystotelesa; por. Etyka Nikomachejska 3,4, p.1146 b 9 i nn. 119 Stromateis III $4,1-2$.

120 Tanze III 59,1-2.

121 Tamze III 57,1-2; por. Mt 7,7. 
którą ma obowiazek kochać /po chrześcijańsku/, $11 \theta \mathrm{z}$ uswleconej 1 roztropnej woli płodził dzieci"122 ... "Męźczyzna powinien być wstrzemiéziliwy i panować nad przyjemnościami, tak samo kobieta powinna być wstrzemięźliwa wównym stopniu i dbała o skuteczna walke z przyjemosciani". /... / "Zabiegac o mstrzemiezzliwość, o sprawiedliwośc 1 wszelkg Inna cnote powinni jednakowo kobieta 1 męzczyzna"123.

Powściągliwośc nie oznacza w żadnym wypadku postawy abnegacji. Chodzi, owszem, o rezygnacje z wartości mniejszej, lecz na rzecz wartośc1 najwyższej, jaka jest miłość Boga:

"A co dotyczy nas samych, to my cenimy powściagli-
wośc wysoko, a to ze względu na nasza miłośćdo
Pana i ze względu na samo pięno moralne, w ten
sposób oddajac cześc przybytkowi Ducha. Jest wszak
pięnie pozbawić samego siebie ze względu na
królestwo niebieskie wszelkiego pożadania i swe
sumienie oczyszczać z czynów martwych, aby słuzyć
Bogu zywemu "124.

W sumie powściaggliwosć, w stosunku do mlłości Boga, pełni Punkcję przygotowawczą, likwidując namiętności i zainteresowanie wartościami nizszymi. Małzonkowie skupieni na Bogu uświęcaja swe życie małzeńskie 1 rodzinne trwajłc w łączności z Tyin, który jest jedynym źródłem śriętośc1.

Cnoty wspomagajłce. Małzeństwo chrześcijańskie, wszczepione przez chrzest w życie Trójcy Swiętej, dążące do zgody i jednomyślnośc1 z Bogiem przez miłość 1 powściagliwość, jest święte. Klemens wypowie te prawde expressis verbis w dyskusji z heretykan1: "ǎy yłuoc-"swięte jest małzeństwon125. W zyciu codziennym świętość ta dopełnia się przez praktykę rozmaitych cnót pomocniczych. W tym zakresie Klemens bardzo często odwołuje się do wskazań podanych przez §w.Pawła. Innych cnót żąda od męza i ojca rodziny, innych od żony 1 matki, jeszcze innych od dzieci.

122 Stromateis III 58,2 .

123 Tamże III 59,$3 ; 60,3$.

124 Tamie III 59,4; por. 1 Kor 3,16 ; Mt 19,12 ; Hbr 9, 14.

125 Stromateis III 84,2 . 
Mąz 1 ojciec winien, jego zdaniem, wyrózniać sié troskliwością o cały dom. Troszczac się "o zycie całej swej rodziny ucieleśnia on nieudolnie miniaturze odbicie prawdziwej Opatrzności"126.

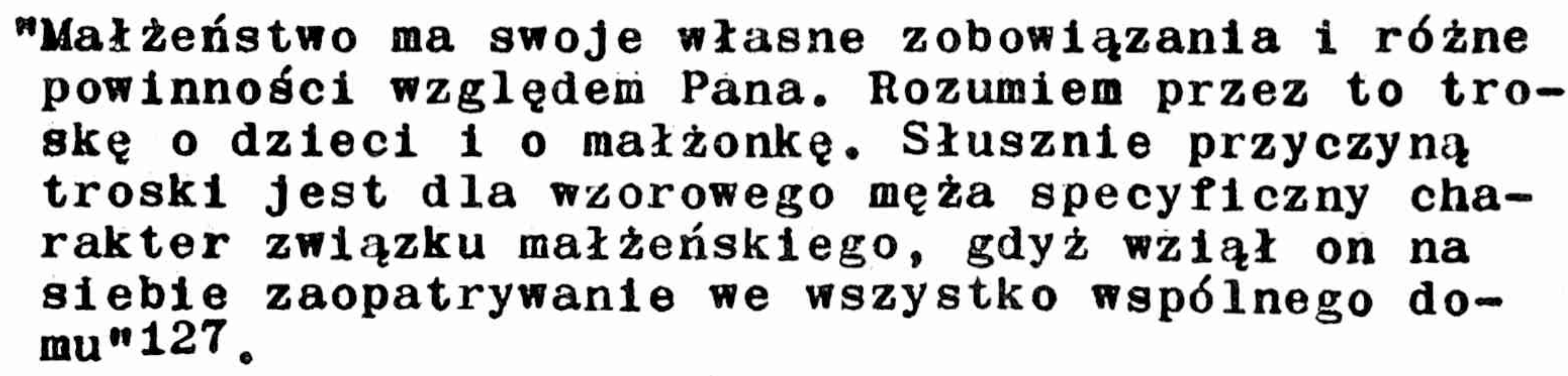

Troskliwośc ta obejmuje nte tylko sprawy materialne i duchowe. ojciec rodziny ma być tym, który zajmuje się "kształceniem 1 wychomaniem dzieci w Panu zgodnie z wola Logosun128. Prócz tego winien okazywać dobroć i wyrozumiałość względem żony i dzieci"129.

Zona winna cechowac sie uległościa 1 wiernościa waględem męza ${ }^{13}$, dobrym usposobieniem, rozwagą, łagodnością, milczeniem, clerpliwościa i gospodarnościa. Kobiety starsze winny zachęcać młode niewiasty "do utrzymania slę miłości małżeńskiej, w rozwadze, w ślątobliwości, w gospodarności, w dobroci, w podporządkowaniu własnerau mz̨żowi, tak, aby nauka Boża nie uległa zniesł̣awieniu"131. Żona winna łagodzić napięcia atmosfery domowej:

$$
\begin{aligned}
& \text { "Jasne jest, jak sądze, że każdá z nadarzajłcych } \\
& \text { si q prowadzeniu domu przykrości ze strony męza } \\
& \text { postara słę wyrownać słowem w drodze perswazji"132. }
\end{aligned}
$$

W ublerantu i upiększaniu powinna cechować się "szlachetnym umiarem"133. Ma być " pomocniçz męża zarówno w zarządzie gospodarstwem domowym jak w zakresie wiary wezusa Chrystusa" ${ }^{134}$.

Dzieci, pouczone słowem Bożym przez rodzlców, zostają nieJako powołane do nowego zycia w Duchu i przez to stajc się uczestnikami świętości swych rodziców. Fakt ten wyjaśnia klenens następuJąco:

126 Tamże VII 70,8 .

127 Tanże III. 79,5 .

128 Tamze III 98,4 ; por. VII 80,4 .

129 Tamże IV 65, 1; por. Kol 3,18-4,1.

130 Stromateis IV 65,1; por. Kol 3,18.

131 Stromateis IV 128,1; por. Tt 2,3-5; Stromateis IV 108,3;

1 Tym 5,21. 
"Jak to, cosiz rodzi z ciała, jest ciałein, tak to, co sie rodzi z Ducha, jest Duchem $\gg$ odnosi się nie tylko do urodzin, lecz 1 do nauczania. W ten sposób świętość staje się też udziałen dzieci, które sł miłe Bogu,gayz słowa Pańskie zaręczyły z Nim ich dusze"135.

$\mathrm{Z}$ cnót, które winny posiadać dzieci, akcentuje Klemens posłuszeństwo, gdy za ś. Pawłem cytuje: "Dzleci, bądźcie uległe rodzicom we wszystkim, to mianowicie szczególnie miłe jest Panu"136.

Cnoty wspomagające są szczegółowym rozpracowaniem programu codziennego doskonalenia chrześcijańskiego. Wszystkie bowiem razem prowadza do zacieśnienia wopólnoty życla z Bogiein, do wzrostu doskonałej agape oraz budowanta świętosci małzeństwa i rodziny.

W nauce Klemensa Aleksandryjskiego daja sié wyróżnić dwa odrębne nurty: apologetyczno-polemiczny oraz dogmatyczno-moralny. W pierwszym rystępuje klemens jako niezrównany polemista zbijający po kolei paradoksalne 1 niedorzeczne twierdzenia heretyków, oparte na fałszywej egzegezie 1 blędnej metodologil. Broniac godnośc1, Wzniosłości i św lętości maxżeństwa i rodziny, nie popada * skrajność, lecz trzyma sle wieinie stoickiej mezotes.

Rozumiejac dobrze wagi zagrozenta, nie poprzestaje na odparciu zarzutów i obronie, lecz, jako pierwszy pisarz ortodoksyjny po św. Pawle, szerzej traktuje o małzeństwie 1 rodzinie, stajac sie proklamatorem lch godności i świg̨iości. W jego nauce występuje uderzająca jasność 1 logika. Zródiem świętości jest wszczepienie małzonków w zycie Boże przez chrzest i ciłgła obecność Boga nich, Droga do świętości jest dążente do zgodności życia małźonków z źyciem Bozym, realizowane w dwóch etapach: 1. 1ikwidowanie zła, które łamie jednomyślność /zgodę/z Bogiem; 2. dazżenie do cnoty, która buduje jednomyślność/zgodę/z Bogiem. W analizomaniu programu "zgody"/homonoia, homologia/ trzyma sie w zasadzie linil Paw wej, nie stroniac jednak od inspitracji stoicko-platońskich, co nie przeszkadza, że zasady przez niego głoszone zachowuja po dziś dzień swói nieprzemijający walor doktrynalny 1 praktyczny.

Ks. Franciszek Draczkowski - Lublin

135 Tamíe III 84,3 ; por. J 3,$6 ; 1$ Kor 7,14 .

136 Stromateis IV 65,1 ; por. Kol 3,20 . 
DIE HEILIGKEIT VON EHE UND FAMILIE NACH KLEMENS VON ALEXANDRIEN /Zus ammenfassung/

Wenn nach der Genese der Lehre des Klemens von Alexanärien von der Heiligkeit der the und der Familie gefragt wird, dann muB die Situation der Bedrohung berticksichtigt werden, in der diese im 2 . Jahrhundert n.Chr. sowohl von ausschwelfenden als auch von rigorist1schen Sekten scharf angegriffenen Institutionen standen. Diese Sekten stellten die gottliche Elnsetzung der Ehe in Frage, verurte1lten den Geschlechtsakt als die Menschenwthre schmblernd und lehnten die Geburt als byse und von Gott verflucht ab. Klemens zelgt, daB diese Ansichten, die slch aup oine falsche Exegese der Heiligen Schrift und eine irrige Methodologie voller Widersprtiche und Paradoxe statzen, das gottliche Werk der Schopfung blasphemisch schmblern. Er beweist, daB die gottliche Einsetzung der Institution der Ehe deren Helligkeit verburgt und der Vervollkommnung des Menschengeschlechts dient. Der eheliche Verkehr entspricht der Natur und dem Willen Gottes, und Christus, der selbst an der Geburt Antell hatte, helligte und segnete diese. Die Quelle der Helligkeit der the 1st die Taufe, die die Stlnden abwasht, uns zu Syhnen macht und Te11name an der gottmenschlichen Gemelnschaft der Kircho gewhrt. Das Ehe- und Familienleben wird erhaben durch die standige Gegenwart Gottes, den Innigen Glauben und das Gebet.

Verbunden mit der Quelle der Helligke1t, die Gott selbst ist, realisioren die theleute zusammen mit ihren Kindern ein Programm der Vervolikommnung und Heiligung, das als standiges Streben nach Immer groberer Jboreinstimmung des eigenen Lebens mit dem gottlichen Leben verstanden w1rd. Dieser ProzeB umfaBt zwei Etappen: 1. die Uberwindung dessen, was die Einmatigkeit mit Gott verletzt, d.h. die Abwehr des Bosen; 2. das Streben nach dem, was die Ubereinstimmung mit Gott herbeifuhrt, $d_{\circ} h$. das Bemlihen um die Tugend. Zu den wichtigsten Tugenden des Ehe- und Familienlebens zahlt Klemens die christliche Liebe /agape/ und die Selbstbeherrschung/enkrateia/. Als Hilfstugenden nennt er: die Gate, die Sanftmutigkeit, die Geduld, die Wirtschaftlichkeit, die Sorge ums Heim, den Gehorsam und die Bescheidenheit. Klemens erwelst sich in seinen Schriften als Verteidiger und feierlicher Verkander der Heiligkeit von Ehe und Familie. 